\title{
Expedition 331 summary ${ }^{1}$
}

\author{
Expedition 331 Scientists $^{2}$
}

\section{Chapter contents}

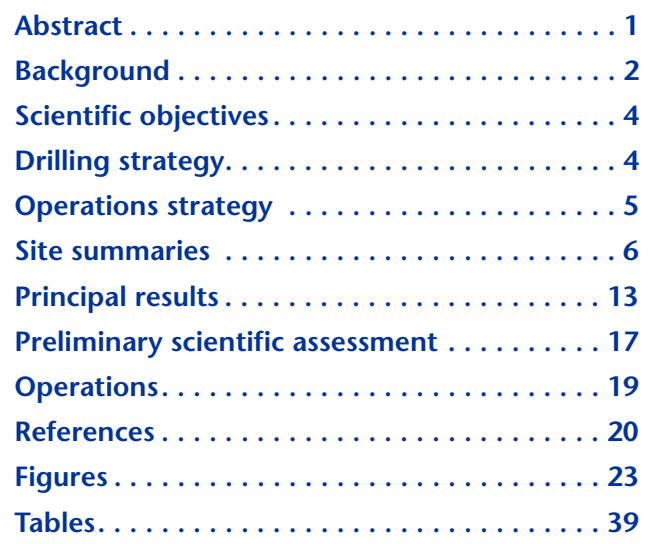

'Expedition 331 Scientists, 2011. Expedition 331 summary. In Takai, K., Mottl, M.J., Nielsen, S.H., and the Expedition 331 Scientists, Proc. IODP, 331: Tokyo (Integrated Ocean Drilling Program Management International, Inc.). doi:10.2204/iodp.proc.331.101.2011 'Expedition 331 Scientists' addresses.

\section{Abstract}

The Iheya North hydrothermal field is located in the middle Okinawa Trough, an actively spreading backarc basin that extends for $1200 \mathrm{~km}$ between the Ryukyu arc-trench system and the Asian continent in a transitional region between continental and oceanic crust. Because the Okinawa Trough contains both hemipelagic and volcanic sediment, in some places $>1000 \mathrm{~m}$ thick, its hydrothermal systems provide abundant $\mathrm{H}_{2}, \mathrm{CO}_{2}, \mathrm{CH}_{4}, \mathrm{NH}_{4}, \mathrm{H}_{2} \mathrm{~S}$, and $\mathrm{CO}$ derived from sedimentary organic matter and from magmatic gases that could feed a variety of microbial communities, sustained by different chemolithoautotrophic primary producers within a range of subseafloor habitats. Integrated Ocean Drilling Program (IODP) Expedition 331, the Deep Hot Biosphere project, drilled into the Iheya North hydrothermal system in order to investigate metabolically diverse subseafloor microbial ecosystems and their physical and chemical settings.

We drilled five sites during Expedition 331: the active hydrothermal vent site and sulfide-sulfate mound at North Big Chimney (NBC) (Site C0016); three sites east of NBC at distances of $\sim 100$, 450, and $1550 \mathrm{~m}$ from the active vents (Sites C0013, C0014, and C0017, respectively); and one site on a hill $\sim 600 \mathrm{~m}$ northwest of the active vents that represents a potential migration path for hydrothermal fluid (Site C0015). We drilled $708 \mathrm{~m}$ of sediment, of which $560 \mathrm{~m}$ were cored and $312 \mathrm{~m}$ recovered, for an overall recovery of $56 \%$. Our maximum penetration was 151 meters below seafloor (mbsf) at recharge Site C0017. We used heavy, triangular, gimbaled guide bases at three holes, one each at Sites C0013, C0014, and C0016, for reentry, casing, and capping, including installation of a steel mesh platform with valve controls for postcruise sampling of fluids.

At Site C0016, drilling at the summit of the active hydrothermal mound failed to recover core and drilling at the base of the mound yielded only $2.1 \mathrm{~m}$ of core from $45 \mathrm{~m}$ of penetration, but the core included the first Kuroko-type, sphalerite-rich black ore ever recovered from the modern subseafloor. The other four sites yielded interbedded hemipelagic and strongly pumiceous volcaniclastic sediment, along with volcanogenic breccias that are variably hydrothermally altered and mineralized, in the zeolite to greenschist facies. Temperature gradients decrease greatly with distance from the active vents at Site $\mathrm{C} 0016$, from $>7^{\circ} \mathrm{C} / \mathrm{m}$ at Site $\mathrm{C} 0013$ to $3^{\circ} \mathrm{C} / \mathrm{m}$ at Site $\mathrm{C} 0014$ and $0.6^{\circ} \mathrm{C} / \mathrm{m}$ at Site C0017. De- 
tailed temperature profiles at Sites C0014 and C0017 display irregularities suggestive of lateral flow. The profile at Site C0017 is concave-upward, consistent with recharge of cold seawater into the hydrothermal system at this site.

Analyses of interstitial water and headspace gas yielded complex patterns with depth and laterally at most sites over distances of only a few meters. Documented processes include formation of brines and vapor-rich fluids by phase separation and segregation, uptake of $\mathrm{Mg}$ and $\mathrm{Na}$ by alteration minerals in exchange for $\mathrm{Ca}$, leaching of $\mathrm{K}$ at high temperature and uptake at low temperature, anhydrite precipitation, potential microbial oxidation of organic matter and anaerobic oxidation of methane utilizing sulfate, methanogenesis, abrupt changes in composition with depth that result from sealing by relatively impermeable cap rock, and generation of hydrogen at depth, apparently by hydrothermal rather than microbial processes.

Shipboard analyses have not confirmed the presence of an active deep hot biosphere. Cell abundances are much lower than those found in previous Ocean Drilling Program/IODP sites on continental margins, and attempts at culturing (hyper)thermophiles were generally unsuccessful. We did find ample evidence for microbial activity supported by sedimentary organic matter, but only in sediments within the upper 10-30 mbsf where temperatures were relatively low. At inactive discharge Site C0015 and recharge Site C0017 we found a community containing possible iron oxidizers that was successfully cultured.

\section{Background}

Active subseafloor hydrothermal systems at midocean ridges, volcanic arcs, backarc basins, and hotspots are environments with extraordinarily high fluxes of energy and matter. The "subvent biosphere" is the subseafloor biosphere that is predicted to exist just beneath active hydrothermal vents and fluid discharge zones (Deming and Baross, 1993). Subseafloor environments within active hydrothermal systems are promising locations for functionally active, metabolically diverse subseafloor microbial ecosystems. The existence of a subvent biosphere has been inferred from many microbiological and geochemical investigations of vent chimney structures and diffuse hydrothermal fluids (Nunoura and Takai, 2009; Nunoura et al., 2010; Takai et al., 2008, 2009; and references in Takai et al., 2006, and Huber and Holden, 2008). High-temperature hydrothermal fluids with focused discharge and little or no dilution by seawater also provide evidence for indigenous subvent microbes active along flow paths of hydro- thermal upwelling, in which abundant $\mathrm{H}_{2}, \mathrm{CO}_{2}$, $\mathrm{CH}_{4}, \mathrm{H}_{2} \mathrm{~S}$, and $\mathrm{CO}$ provided as magmatic volatiles and by hydrothermal water-rock reactions are metabolized (Takai et al., 2004; Huber and Holden, 2008). Indeed, the possible occurrence of a subvent biosphere has been clearly demonstrated by microbiological and geochemical characterization of hightemperature hydrothermal fluids in several hydrothermal fields (Nakagawa et al., 2005; Nunoura and Takai, 2009; Takai et al., 2004, 2008, 2009). In the Iheya North field, it has been suggested that a variety of microbial communities sustained by different chemolithoautotrophic primary producers is present in subseafloor habitats (Nakagawa et al., 2005). Variability in potential subseafloor microbial communities is likely associated with physical and chemical variation of hydrothermal fluids, controlled by phase separation and phase partition of hydrothermal fluid beneath the seafloor. In addition, hydrothermal environments hosted by organic-rich sediments provide unusual amounts of $\mathrm{C}_{1}$ compounds $\left(\mathrm{CO}_{2}\right.$ and $\left.\mathrm{CH}_{4}\right)$ in hydrothermal fluids as carbon sources, as well as unique microbial habitats affected by liquid $\mathrm{CO}_{2}$ and gas hydrates (Nakagawa et al., 2005; Kawagucci et al., 2011). Thus, the abundant supply of energy and carbon and the richness of the habitats supported by physical and chemical variations in the Iheya North field provide an ideal setting for the formation of functionally and metabolically diverse subseafloor microbial communities associated with hydrothermal activity.

\section{Geological setting and hydrothermal activity in the Okinawa Trough}

The Okinawa Trough is a backarc basin extending for $\sim 1200 \mathrm{~km}$, located between the Ryukyu arc-trench system and the Asian continent (Lee et al., 1980; Letouzey and Kimura, 1986) (Fig. F1). It is presently undergoing rifting, the current phase of which began at $\sim 2$ Ma and was preceded by an earlier rifting episode during the Miocene. Lee et al. (1980) proposed that the Okinawa Trough is presently in a "drifting phase" (i.e., oceanic crust spreading characterized by short spreading centers and concomitant transform faults), as typically occurs along midocean ridges and in other actively spreading backarc basins such as the Lau Basin and Mariana Trough. Seismic reflection data also suggest a typical geologic structure for the Okinawa Trough (Letouzey and Kimura, 1986), consisting of a high-velocity mantle at $\sim 6000$ meters below seafloor (mbsf) overlain by potentially young basalt with an average velocity of $5.8 \mathrm{~km} / \mathrm{s}$ between $\sim 3000$ and $6000 \mathrm{mbsf}$, an igneous rock layer $(4.9 \mathrm{~km} / \mathrm{s})$ between $\sim 1000$ and $3000 \mathrm{mbsf}$, and $\sim 1000 \mathrm{~m}$ of sediment immediately beneath the 
seafloor. Geochemical features of hydrothermal fluids in the Okinawa Trough hydrothermal systems clearly demonstrate a significant contribution from felsic rocks and magma (Glasby and Notsu, 2003), as described below. Thus, it seems likely that the Okinawa Trough is an actively rifting transitional region between continental and oceanic crust.

Integrated Ocean Drilling Program (IODP) Expedition 331 provided an opportunity to drill into an active hydrothermal system and associated deposits within a backarc basin in a continental margin setting. Characteristics of this tectonic setting are reflected in the chemical composition of hydrothermal sulfide deposits there. Sulfide samples collected from the Iheya North field are distinctly more rich in $\mathrm{Pb}$ than mid-oceanic-ridge sulfides (Halbach et al., 1993) (Fig. F2). The polymetallic $\mathrm{Zn}-\mathrm{Pb}-\mathrm{Cu}$ chemical signature of Iheya North sulfides is similar to that of Kuroko-type hydrothermal deposits formed during the Tertiary in northeast Japan and related to the opening of the Japan Sea. Moreover, many volcanic massive sulfide ore deposits formed throughout geologic time are related to felsic and/or intermediate magmatism rather than to basaltic volcanism at typical mid-ocean ridges (Urabe and Marumo, 1991).

The chemistry of hydrothermal fluids collected from active sulfide chimneys in the Okinawa Trough is characterized by higher concentrations of $\mathrm{CO}_{2}, \mathrm{CH}_{4}$, $\mathrm{NH}_{4}, \mathrm{I}$, and $\mathrm{K}$ and higher alkalinity than those in typical sediment-free mid-ocean-ridge hydrothermal fluids (Sakai et al., 1990a, 1990b; Gamo et al., 1991; Konno et al., 2006; Takai and Nakamura, 2010; Kawagucci et al., 2011). The distinctive hydrothermal fluid chemistry is strongly linked with the geologic setting and the thick terrigenous sediments of the Okinawa Trough. Philippine plate subduction along the Ryukyu arc-trench system supplies daciticrhyolitic magma to the Okinawa Trough that is rich in $\mathrm{K}$ and volatile components (Sakai et al., 1990b; Gamo et al., 2006). Organic-rich terrigenous sediment filling the Okinawa Trough (Narita et al., 1990) supplies not only the sedimentary chemical inputs $\left(\mathrm{NH}_{4}\right.$, I, etc.) (Gamo et al., 1991; You et al., 1994) but also promotes the widespread occurrence of functionally active microbial communities that impact hydrothermal fluid chemistry and circulation (Nakagawa et al., 2005; Inagaki et al., 2006; Nunoura and Takai, 2009; Nunoura et al., 2010; Takai and Nakamura, 2010). In addition to the chemical aspects, the relatively shallow water depth of many Okinawa Trough hydrothermal systems serves to induce subcritical phase separation (Suzuki et al., 2008) and subsequent phase segregation, as the boiling temperature of seawater decreases steeply with decreasing pressure at $\sim 100$ bar. Phase separation and segrega- tion sometimes produce hydrothermal fluids of quite different chemical composition at different vent sites in the same hydrothermal field, even though they are derived from the same source fluid (Kawagucci et al., 2011).

Since the discovery of submarine hydrothermal activity at Iheya Ridge and Izena Hole (Halbach et al., 1989; Sakai et al., 1990b) in the middle Okinawa Trough in 1988, six active hydrothermal fields (Minani-Ensei Knoll, Iheya North, Iheya Ridge, Izena Hole, Hatoma Knoll, and Yonaguni Knoll IV) have been discovered. The Iheya North field has been investigated by interdisciplinary methods, specifically geochemistry of hydrothermal fluids and sulfide/sulfate deposits (Glasby and Notsu, 2003; Kawagucci et al., 2011) and microbial ecology at the seafloor (Takai and Horikoshi, 1999; Takai et al., 2003; Nakagawa et al., 2005; Takai et al., 2006; Takai and Nakamura, 2010). It has also been monitored for $\sim 15 \mathrm{y}$.

\section{Seismic studies and site survey data}

Hydrothermal activity in the Iheya North Knoll $\left(27^{\circ} 47.50^{\prime} \mathrm{N}, 126^{\circ} 53.80^{\prime} \mathrm{E} ; 150 \mathrm{~km}\right.$ north-northwest of the island of Okinawa, Japan) was first discovered by a camera survey in 1995. Since then, deep submergence vehicle (DSV) and remotely operated vehicle (ROV) dives have revealed details regarding the location of hydrothermal activity and seafloor events (Fig. F3). Recent seismic and geophysical surveys (Table T1) have provided insights into the subseafloor geologic structure and the pattern of heat flow through the seafloor, suggesting a possible hydrothermal fluid flow model for the Iheya North hydrothermal system.

A grid of multichannel seismic (MCS) profiles has been completed for the Iheya North Knoll region (Fig. F1). MCS profiles across the Iheya North Knoll demonstrate an igneous intrusion penetrating the trough-filling sediments, which are $>1000 \mathrm{~m}$ thick (Fig. F4). In the middle of Iheya North Knoll, a central valley exhibits relatively disordered seismic reflectors as deep as 400-500 mbsf, suggesting the presence of pumiceous volcaniclastic deposits beneath the surficial hemipelagic sediments rather than massive igneous rocks (Fig. F5).

Pumiceous volcaniclastic deposits have been recovered in numerous shallow $(<2 \mathrm{~m})$ gravity cores obtained from the central valley of Iheya North Knoll (Oiwane et al., 2008). In all cores, thick pumice layers with coarse to fine grain sizes were found just below the seafloor. These layers often contain abundant gas-filled voids accompanied by elemental sulfur and sulfide minerals, probably deposited by gas-rich hydrothermal fluids (Masaki et al., 2011). 
These site survey data consistently suggest that multiple and thick volcaniclastic deposits fill the central valley of Iheya North Knoll, providing potential hydrothermal fluid recharge paths, fluid reservoirs, and discharge paths (Kumagai et al., in press).

A significant discovery of the seismic reflection survey is the existence of large-scale negatively polarized reflection sequences deep beneath the hill west of the Iheya North hydrothermal vent sites. The eastern end of these westward-dipping sequences appears to converge at the seafloor where the vent sites are located (Fig. F6). These negative polarity sequences are interpreted to consist of layers of highly porous pumiceous volcanic deposits, which could serve as potential migration paths for subseafloor hydrothermal fluids. The sequences appear to be as thick as $100 \mathrm{~m}$ just beneath the western hill near the vent sites. The negative polarity sequences could also represent a potential fluid reservoir that feeds ascending hydrothermal solutions eastward up to the discharge sites along the westward dipping structure. To determine the possible role of these structures in the hydrothermal system, it would be desirable to penetrate and sample these negative polarity sequences, a process which was not attempted during Expedition 331.

The supporting site survey data for Expedition 331 are archived at the IODP Site Survey Data Bank.

\section{Scientific objectives}

The goal of Expedition 331, Deep Hot Biosphere, was to test for the presence of a functionally active, metabolically diverse subvent biosphere in its physical, geochemical, and hydrogeologic context within the Iheya North field in the middle Okinawa Trough. This work addresses one of the primary themes of the IODP Initial Science Plan: the Deep Biosphere and the Subseafloor Ocean.

This project was conducted by an interdisciplinary group of onboard and shore-based scientists including microbiologists, geochemists, sedimentologists, petrologists, geologists, and geophysicists. The major scientific objectives of Expedition 331 drilling were

1. To test for the existence of a functionally active, metabolically diverse subvent biosphere associated with subseafloor hydrothermal activity in the Iheya North field;

2. To clarify the architecture, function, and impact of subseafloor microbial ecosystems and their relationship to physical, geochemical, and hydrogeologic variations within the hydrothermal mixing zones around the discharge area; and
3. To establish artificial hydrothermal vents in cased holes, using casing with perforated screen pipes at those depths that exhibit hydrothermal flow, and to prepare a research platform at each cased hole for later study of fluids tapped from various parts of the hydrothermal system and their associated microbial and macrofaunal communities.

In our shipboard studies, and continuing postcruise, we have addressed these objectives through a combination of compositional and isotopic biogeochemistry and cellular, molecular, and functional microbiology. We have used downhole temperature measurements, alteration mineral assemblages, and the chemical composition of hydrothermal fluids to constrain the physical and chemical conditions of mineralization and of the microbial habitats. Studies of fluid inclusions in alteration minerals will constrain present and past fluid temperatures and provide evidence for subseafloor phase separation. Isotopic studies of sulfur, lead, and possibly iron will provide information on magmatic and crustal contributions to the hydrothermal system. Dating of hydrothermal deposits will constrain the duration and timing of hydrothermal activity. Application of recently developed microanalytical techniques such as laser ablation-inductively coupled plasma mass spectrometry (LA-ICP-MS) will provide new insight into the sources of hydrothermal metals. Finally, drilling provided some constraints on the hydrology of the active hydrothermal system and the size and geometry of the associated sulfide deposits and alteration zones. Because microbial habitat relies on hydrologic as well as physical-chemical structure, these studies will provide important insights into the range of conditions within the subseafloor biosphere.

\section{Drilling strategy}

We drilled five sites during Expedition 331: the active hydrothermal vent site and sulfide-sulfate mound at North Big Chimney (NBC) (Site C0016) (Fig. F3), three sites east of NBC at distances of $\sim 100$, 450, and $1550 \mathrm{~m}$ from the active vents (Sites C0013, C0014, and C0017, respectively), and one site on a hill $\sim 600 \mathrm{~m}$ northwest of the active vents that represents a potential migration path for hydrothermal fluid (Site C0015) (Fig. F6).

The NBC hydrothermal mound at Site C0016 is $20 \mathrm{~m}$ high and $6 \mathrm{~m}$ in diameter (Fig. F7). We attempted to drill one hole into an active high-temperature $\left(310^{\circ} \mathrm{C}\right)$ vent at its summit in which the pipe broke and we failed to recover any core. We drilled a second hole $20 \mathrm{~m}$ away, immediately at the base of the 
mound on its western side. Because of the high temperatures and because we expected to recover hard rock, we used conventional hard rock drilling equipment supplied by Baker-Hughes Inteq (BHI) specifically for Expedition 331. The BHI system collects 4 inch diameter core in aluminum liners in lengths of 9,18 , or $27 \mathrm{~m}$, but the cores cannot be retrieved by wireline and so require a time-consuming pipe trip for each core.

At Sites C0013, C0014, and C0017, we drilled the relatively high, moderate, and low heat flow areas to the east of the Iheya North hydrothermal field to investigate subseafloor microbial habitats and communities within broad gradients of physical and chemical variation, both laterally and vertically, that could be affected by mixing between discharging hydrothermal solutions and recharging ambient bottom seawater. These sites were drilled using the hydraulic piston coring system (HPCS) to first refusal and then again in any softer intervals encountered deeper in the hole, alternating as necessary with the extended punch (EPCS) and extended shoe (ESCS) coring systems, and, for one run at Site C0013, the BHI system, to penetrate the harder layers. Both the EPCS and ESCS systems were able to penetrate the harder layers, with a slight edge to the ESCS for the hardest, but the EPCS was generally much better at core recovery.

We penetrated the margin of the local discharge-recharge zone to depths of 55, 137, and 151 mbsf at Sites C0013, C0014, and C0017, respectively, coring variably hydrothermally altered sediment and pumiceous deposits (Fig. F5). We were able to measure in situ temperature at two of these sites using the advanced piston corer temperature tool (APCT3) shoe (upper calibration limit $=55^{\circ} \mathrm{C}$ ) as part of the HPCS, combined with commercial thermoseal (Nichiyu Giken Co., Ltd.) strips taped to the outer surface of the core liner. The strips estimate temperature in $5^{\circ}$ or $10^{\circ} \mathrm{C}$ increments using chemically impregnated wafers that turn black when exposed to the designated temperature. They can each be used over one of several limited ranges between $75^{\circ}$ and $250^{\circ} \mathrm{C}$. Temperature measured at the distal flank Site C0017 reached $44^{\circ} \mathrm{C}$ at $112 \mathrm{mbsf}$ and $90^{\circ} \mathrm{C}$ at $151 \mathrm{mbsf}$. Temperature at the intermediate flank Site C0014 was $22^{\circ} \mathrm{C}$ at $6.5 \mathrm{mbsf}$; it exceeded $55^{\circ} \mathrm{C}$ at $16 \mathrm{mbsf}$ and exceeded $210^{\circ} \mathrm{C}$ at only 50 mbsf. We were not able to measure temperature at proximal flank Site C0013, but the gradient was likely higher than at the other two flank sites. This contention is based on the alteration mineral assemblages and the fact that the acrylide plastic core liners began to melt, which during onboard tests began to soften and deform at $82^{\circ} \mathrm{C}$, at only $12 \mathrm{mbsf}$. Melting of the plastic core liners severely limited our ability to core to depth at
Site C0013. Our one attempt to use the BHI system at this site, with its 4 inch diameter aluminum core liners, recovered only $2.1 \mathrm{~m}$ of core from a $9.2 \mathrm{~m}$ penetration and required nearly $22 \mathrm{~h}$ to collect, mainly because the interval included soft layers and the BHI system is optimized for hard rock coring. During the port call in Okinawa halfway through Expedition 331, we acquired eighteen $9 \mathrm{~m}$ sections of standard 2.44 inch diameter aluminum core liner, which were mostly used to retrieve good quality core to the depth we reached at Site C0014.

Site C0015 is located $600 \mathrm{~m}$ northwest of the hydrothermal mounds, where the seismically detected negative polarity sequences become thick. We targeted for drilling a heavy concentration of shells of dead mussels, which suggest that methane-rich hydrothermal fluids upwelled here in the recent past. We saw no live mussels at this site. Up to $400 \mathrm{~m}$ of penetration would be required to penetrate the deepest of the negative polarity reflectors, but we had time to take only two HPCS cores to 9.4 mbsf before we had to depart for Okinawa for a crew change midway through the expedition.

\section{Operations strategy}

All drilling from the D/V Chikyu is continuously monitored at the seafloor using a video camera mounted on an ROV operated by Oceaneering, Inc. This device was invaluable for observing drilling induced hydrothermal flow. We used heavy triangular, gimbaled guide bases at three holes, one each at Sites C0013, C0014, and C0016, to allow reentry for deep drilling and for postdrilling operations, including casing and capping. The casing in each of these holes was hung from the guide base, a valved wellhead corrosion cap was fit over the hole, and a steel mesh platform with valve controls was installed on its top. Holes C0013E and C0014G were cased to total depth, using perforated screened casing in depth intervals where flow was thought to occur. Hole C0016B was not cased, but it was capped, with a $3 \mathrm{~m}$ piece of pipe welded beneath it as a substitute for full casing of the $45 \mathrm{~m}$ deep hole. The research group of Co-Chief Scientist Ken Takai has recently developed an in situ cased-hole fluid sampler (DEEP-SAMPLER) and a microbial colonization device (BIO-SAMPLER). These sampling tools will enable them to retrieve indigenous subseafloor fluids and microbes at the seafloor through these cased holes using an ROV. Development of these types of third-party tools greatly extends the usefulness of IODP drill holes, provides research opportunities for investigating subseafloor fluid flow and microbial communities, and permits long-term monitoring of drilling-induced disturbance of seafloor and subseafloor environments. 


\section{Site summaries}

\section{Site $\mathrm{C0013}$}

\section{Operations, stratigraphy, minerals, and physical properties}

Eight holes (C0013A-C0013H) were drilled at Site C0013 (see Fig. F2 in Expedition 331 Scientists, 2011a), and core was recovered from all but Hole C0013A (Fig. F8). Hole C0013E was the deepest (54.5 mbsf) and was cased down to 40.2 mbsf and fixed with a corrosion cap (open outlet pipe) mounted on the guide base. During drilling and coring operations at Site C0013, we encountered many operational and sample-handling problems. These problems were due to the unexpectedly high temperature gradient at the site and the presence of repeated hard layers that appear to behave as cap rocks alternating with soft and sticky clay-rich layers. Porosity measurements on the core clearly document the repeated occurrence of low-porosity harder layers (e.g., 0-2, 710 , and 20-30 mbsf). We observed at several depths that when a hard cap rock was drilled through into softer underlying layers, subseafloor hydrothermal fluid began to upwell from the hole to the seafloor, where it was imaged by the ROV video camera. We surmise that fluids were flowing laterally, trapped beneath the cap rock. To tap this fluid, we used slotted, perforated casing pipe over the depth interval 2139.8 mbsf in Hole C0013E (Fig. F9). Immediately after casing and capping this hole, we observed in the ROV video image strong hydrothermal fluid discharge from the casing pipe that was hung in the guide base. Thermoseal temperature-sensitive strips on the corrosion cap outlet pipe and read in the ROV video imagery indicated that the discharging water was $>250^{\circ} \mathrm{C}$. When the JAMSTEC ship Natsushima visited Hole C0013E with its Hyper Dolphin ROV 2 days later, they found that flow from the casing pipe through the outlet in the corrosion cap had ceased. Instead, water that appeared blackish was now discharging directly from the hole beneath the guide base. This flow apparently came up through the annulus, between the wall of the hole and the outer surface of the casing pipe. The Hyper Dolphin lowered a probe $30 \mathrm{~m}$ into cased Hole C0013E and measured a temperature of only $4^{\circ} \mathrm{C}$; the hole was plugged below that depth. The Hyper Dolphin also measured a temperature of $11^{\circ} \mathrm{C}$ in diffuse flow from uncased Hole C0013D, higher than the bottom water temperature in the area of $4.51 \pm 0.17^{\circ} \mathrm{C}(1 \sigma, n=4$; measured at Holes C0014C, C0014D, C0014F, and C0014G). On these same dives the Hyper Dolphin revisited the NBC vent $\sim 170 \mathrm{~m}$ to the west-northwest, which we drilled as Site C0016, and found it to be venting $310^{\circ} \mathrm{C}$ fluids, compared with the highest temperature measured there in previous years of $311^{\circ} \mathrm{C}$ (Kawagucci et al., 2011).

Four lithologic units were identified at Site C0013. The uppermost Unit I (0-5 mbsf) is hydrothermally altered mud containing crystalline pipes of elemental sulfur and sulfide grit. The ROV survey done at the site to choose actual hole locations shows that the seafloor is covered by a thin $(<1 \mathrm{~m})$ discontinuous layer of unaltered sediment, as has been documented in previous surveys over the past $10 \mathrm{y}$.

Unit II (5-14 mbsf) is hydrothermally altered mud with some heavily veined intervals and clastic units containing anhydrite breccia and fragments of metalliferous massive sulfide. Unit II is commonly cut by anhydrite veins, indicating that seawater infiltrated and was heated to $>150^{\circ} \mathrm{C}$. Unit II represents a possible hydrothermal reservoir or fluid migration path, consistent with our observation of upflow in Hole C0013E.

Unit III (14-26 mbsf) consists of hydrothermally altered mud, some layers of which contain abundant nodular anhydrite. Unit III was distinguished from Unit II by the presence of large whole anhydrite nodules and less abundant vein anhydrite. Unit III likewise experienced high temperatures $\left(>150^{\circ} \mathrm{C}\right)$ and hosted hydrothermal flow.

Unit IV consists of volcanic breccia with clasts of various volcanic lithotypes. Both monomictic and polymictic breccia were observed, and all were matrix supported and silicified. Other volcanic components within the breccia include clasts of pumiceous to vesicular, flow-banded lava. The occurrence of various volcaniclastic components such as lava, vesiculated glass, breccia, and blocks of polymictic breccia is consistent with breccia formation by mass wasting of a mixture of volcaniclastic units, initially deposited farther upslope from Site C0013.

Hydrothermal alteration assemblages at Site C0013 support the interpretation that the site is a location of recent high-temperature discharge. The uppermost sediments exhibit kaolinite-muscovite alteration and contain variable thicknesses of sulfide-rich material, interpreted as eroded nearby chimneys, to $\sim 5$ mbsf. Native sulfur is also abundant near-surface, which, together with the abundance of kaolinite, suggests highly acidic fluids, interpreted to be caused by oxidation of $\mathrm{H}_{2} \mathrm{~S}$ dissolved in the hydrothermal fluid or released from the fluid during decompression. Below $\sim 5 \mathrm{mbsf}, \mathrm{Mg}$ chlorite and anhydrite are the dominant alteration phases to $\sim 26 \mathrm{mbsf}$, at which point a hard sequence of quartz-Mg chloritealtered volcanic breccia with scattered quartz is intersected. This material is interpreted to be volcanic basement and extends to a depth of 45 mbsf in Hole 
C0013E, the deepest hole at the site. Although it is difficult to estimate alteration temperatures from clay and phyllosilicate mineralogy, transitions seen at Site C0013 are consistent with temperatures of $\sim 150^{\circ}-200^{\circ} \mathrm{C}$ for the uppermost kaolinite-bearing sequence and $\sim 220^{\circ}-300^{\circ} \mathrm{C}$ for the $\mathrm{Mg}$ chlorite-rich sediments and rocks below $\sim 5$ mbsf.

The transition from kaolinite-muscovite-rich to chlorite-rich rocks with increasing depth at Site C0013 is similar to the gradation from paragonitized to chloritized rocks that is documented for the basement underneath the Trans-Atlantic Geotraverse (TAG) hydrothermal mound at the Mid-Atlantic Ridge $\left(26^{\circ} \mathrm{N}\right)$ (Humphris et al., 1995). The difference in mineralogy between Iheya North and the Mid-Atlantic Ridge is partially explained by the lack of iron and the abundance of potassium available within the sequence at the site, compared to the mafic volcanic rocks of the mid-ocean-ridge setting.

The final alteration phase seen at Site C0013 is coarse-grained anhydrite veining, which overprints both kaolinite-muscovite-bearing and $\mathrm{Mg}$ chloritebearing alteration between depths of $\sim 4$ and $\sim 10$ mbsf. This alteration is interpreted to have been formed by heating of downwelling seawater to a temperature of $150^{\circ} \mathrm{C}$ as the system cooled.

We observed the strongest discharge of hydrothermal fluid after using the BHI system for the first time to drill the interval 26-35.2 mbsf. Beneath that depth, to the total depth of 54.5 mbsf in Hole C0013E, our total recovery was $25 \mathrm{~cm}$ of rock. Drilling records indicate that the material we failed to recover became soft again below 35.2 mbsf, suggesting that additional porous and permeable formations exist below Unit IV.

\section{Interstitial water chemistry}

A total of 26 whole-round samples were processed for chemical analyses of interstitial water at Site C0013, from five different holes (C0013B and C0013D-C0013G). Chloride, the major anion in seawater, is nearly constant with depth in Holes C0013B and C0013D at the concentration in seawater. In Hole C0013E, however, it varies widely, from $34 \%$ lower than seawater to $12 \%$ higher in the deepest sample from 17 mbsf. The major cation in seawater, $\mathrm{Na}$, generally follows $\mathrm{Cl}$, as expected from charge balance constraints. $\mathrm{Na} / \mathrm{Cl}$ and $\mathrm{Na} / \mathrm{Br}$ are higher than in seawater in Hole C0013B, probably because of expulsion of $\mathrm{Na}$ from ion exchange sites in clay minerals by other cations, but these ratios decrease systematically with depth to values lower than seawater in the other two holes, showing that $\mathrm{Na}$ is being removed from the seawater-derived pore water into alteration minerals over this interval and at greater depth.

$\mathrm{Mg}$ increases with depth in Holes C0013B and C0013D, probably because of ion exchange with clays as for $\mathrm{Na}$, but decreases to only $7 \mathrm{mM}$ in Hole C0013E. Ca increases irregularly with depth in all three holes, to concentrations nearly five times that in seawater. Although some of this increase is typical for hydrothermal solutions, as $\mathrm{Ca}$ is leached from the host rock, much of the increase at Site C0013 undoubtedly results from anhydrite that is distributed abundantly throughout much of the core and which likely redissolved during the 3-25 $\mathrm{h}$ that elapsed between the arrival of the core on deck and squeezing of the sediment to separate pore water. Dissolution of anhydrite is also implied by the drastic increases in sulfate. By contrast, sulfate decreases with depth in Hole C0013E to less than half the concentration in seawater, as would be expected from anhydrite precipitation within the hydrothermal system with increasing temperature.

The deepest sample obtained from this site, from Hole C0013E at 17 mbsf, is in many ways a typical high-temperature subseafloor hydrothermal fluid. Relative to seawater, it is slightly briny at $623 \mathrm{mM}$ $\mathrm{Cl}$; it has highly elevated $\mathrm{Ca}, \mathrm{K}, \mathrm{Rb}$, and $\mathrm{Cs}$ and greatly depleted $\mathrm{Mg}$ and sulfate; it also has lower $\mathrm{Na}$, presumably lost to the altered rocks.

\section{Microbiology}

The abundance of microbial cells was evaluated by a fluorescent microscopic analysis using SYBR Green I as a fluorochrome dye. Total cell counts obtained from core samples at Site C0013 are generally lower than the detection limit of our onboard counting method $\left(4.4 \times 10^{6}\right.$ cells $/ \mathrm{mL}$ sediment $)$ and are the lowest among all coring sites in this expedition. Microbial abundance in the sediment of the Iheya North hydrothermal field is known to be relatively low $\left(<2 \times 10^{7}\right.$ cells $/ \mathrm{mL}$ sediment) (J. Ishibashi et al., unpubl. data), but the cell abundances we observed are even lower than those previously found. Cultivation tests were conducted for Thermococcales (e.g., Thermococcus spp.) and Aquificales (e.g., Persephonella spp.) and thermophilic Epsilonproteobacteria (e.g., Nitratiruptor spp.) using core from Site C0013 and different recipes for media at various temperatures. No growth of these organisms was identified in the onboard experiments.

Although onboard microbiological measurements and experiments were quite limited and did not provide any conclusive result, it is evident that there is no sizable microbial population in the subseafloor environments at Site C0013. Except for the upper 
several meters below seafloor of altered sediment, subseafloor environments are at higher temperatures $\left(>150^{\circ} \mathrm{C}\right)$ than microbes can survive. However, it is still possible that shore-based work will yield evidence for functionally active hyperthermophilic microbial communities at Site C0013.

\section{Site C0014}

\section{Operations, stratigraphy, minerals, and physical properties}

Seven holes were drilled at Site C0014 (Holes C0014A-C0014G) (Fig. F10; see Fig. F1 in Expedition 331 Scientists, 2011b). Hole C0014G was the deepest (136.7 mbsf) and was cased down to $117.8 \mathrm{mbsf}$ and fixed with a corrosion cap (open outlet pipe) mounted on the guide base. As at Site C0013, we encountered repeated hard layers that may behave as cap rock, and we saw discharge from the holes, beyond what may be expelled drilling fluid only, after penetrating these layers (35-44.5 mbsf in Hole C0014B, 25.5-35 mbsf in Hole C0014E, and 37.747.2 mbsf and 89.2-93.7 mbsf in Hole C0014G). We again cored multiple low-porosity layers (e.g., in Holes C0014B, C0014E, and C0014G). Based on pore water chemistry, density, and porosity (and indicated by low recovery during drilling), we infer lateral hydrothermal flow at 31-425 and 90-95 mbsf at Site C0014. We therefore installed slotted, perforated casing pipe at 29.8-49.2, 78.3-97.8, and 107.5-117.2 mbsf in Hole C0014G (Fig. F9). After casing and capping, we saw in the ROV-mounted video diffuse hydrothermal fluid discharge, not from the corrosion cap outlet but from the seafloor, through the annulus, the space between the wall of the hole and the casing pipe. The temperature of the diffusing fluids was found to be $>240^{\circ} \mathrm{C}$ based on exposure of thermoseal strips mounted on the corrosion cap outlet pipe and observed by ROV.

We measured temperature at Site C0014 using the APCT3 temperature shoe on the HPCS core barrel for lower temperatures $\left(0^{\circ}-55^{\circ} \mathrm{C}\right)$ and thermoseal temperature-sensitive strips for higher temperatures $\left(75^{\circ}-250^{\circ} \mathrm{C}\right)$. The temperature-depth profile at Site C0014 is shown in Figure F11. Temperature increases nearly linearly at $3^{\circ} \mathrm{C} / \mathrm{m}$ to $145^{\circ} \pm 5^{\circ} \mathrm{C}$ at $47 \mathrm{mbsf}$ and then increases abruptly to $>210^{\circ} \mathrm{C}$ at $50 \mathrm{mbsf}$, below a hard layer near that depth.

The drilled sequence at Site C0014 comprises interbedded, variably altered, and consolidated volcaniclastic gravels and breccias, as well as hemipelagic mud. Given the location of the site on the upper flank of an active volcanic complex, mass wasting and debris flows are likely to be important sedimen- tary processes, potentially leading to high rates of redeposition of both hemipelagic and volcaniclastic material. The deeper portion of the rock volume cored has been hydrothermally altered. Differing degrees and styles of hydrothermal alteration form the basis for the division of Site C0014 sediments and lithologies into lithostratigraphic units.

Unit I, the stratigraphically highest unit, shows little evidence of hydrothermal alteration and comprises a succession of coarse angular woody pumice gravels and hemipelagic mud. Unit I extends to $\sim 10-18$ mbsf across Site C0014. It includes a diversity of foraminifers dominated by warm forms of the planktonic Neogloboquadrina pachyderma, some of them pyritized. Minor coccoliths were present, dominated by Emiliania huxleyi, Gephyrocapsa oceanica, and Reticulofenestra asanoi. The contact between Unit I and Unit II may be gradational or sharp and is somewhat arbitrarily defined by increasing hydrothermal alteration, which is expressed in drill core by breakdown of pumice texture and mineralogy and bleaching of hemipelagic mud. Unit II consists of partially consolidated hydrothermally altered mud and hydrothermally altered coarse angular pumice gravels. Clasts of pumice have been devitrified to soft clay that retains its woody texture. Unit II is 12 to $30 \mathrm{~m}$ thick with a base at 29-45 mbsf. Unit III is characterized by the occurrence of consolidated and often cemented volcanic sediments as lithoclasts within breccia or thin horizons interbedded with hydrothermally altered indurated mud. The greatest thickness of Unit III was encountered in Hole C0014G from 29 mbsf to the deepest recovered core at 128 mbsf.

Hydrothermal alteration at Site C0014 shows a change, with increasing depth, from illite/montmorillonite-bearing to $\mathrm{Mg}$ chlorite-bearing rocks at 25-30 mbsf. Mg chlorite implies alteration temperatures of $\sim 220^{\circ}-300^{\circ} \mathrm{C}$, which is broadly consistent with the current temperature data at the site. Anhydrite is present at depths $>57$ mbsf in Hole C0014G, mostly in millimeter-scale irregular veinlets with halite but in much lower abundance than was seen at Site C0013. Primary volcanosedimentary mineralogy is also partially preserved throughout the altered sequence at Site C0014, implying a significantly lower fluid flux than that at Site C0013. Pyrite occurs only at extremely low abundances, mostly as fine-grained disseminations and very rare millimeter-scale veinlets throughout the sequence. These observations are consistent with the interpretation that Site C0013 represents a site of recent high-temperature discharge, whereas Site C0014 is a "background" location within the hydrothermal system at Iheya North. 


\section{Interstitial water chemistry}

A total of 75 whole-round samples were processed at Site C0014 from four different holes. Within the uppermost $\sim 30 \mathrm{~m}$ of sediment, these holes exhibit considerable spatial variation in the concentrations of those chemical species that are most influenced by organic matter diagenetic reactions.

The most sulfate-depleted interval, at 31-41 mbsf, also has the highest $\mathrm{NH}_{4}$ and notable depletions in $\mathrm{Cl}$ and possibly $\mathrm{Br}$. High $\mathrm{NH}_{4}$ and low $\mathrm{Cl}$ typically result from high-temperature phase separation into a brine and a gas-rich, Cl-depleted vapor, as has happened at high-temperature vents in the Iheya North field (Kawagucci et al., 2011; Takai and Nakamura, 2010). Surprisingly, $\mathrm{NH}_{4}$ in Hole C0014G is also inversely correlated with sulfate $\left(\mathrm{NH}_{4}=-0.0556 \mathrm{SO}_{4}+\right.$ 1.7 , in $\mathrm{mM} ; r^{2}=0.88$ for Hole C0014G), as would result in part from the anoxic, ammonia-oxidizing, sulfate-reducing microbial metabolism recently predicted by thermodynamic calculations of microbial energy metabolisms (Schrum et al., 2009).

Below 50 mbsf in Hole C0014G, $\mathrm{Cl}$ and $\mathrm{Br}$ are enriched relative to seawater as they would be in a brine. Sodium, as the major cation in seawater, generally follows the distribution of $\mathrm{Cl}$, but $\mathrm{Na} / \mathrm{Cl}$ is slightly lower than in seawater because of removal into alteration minerals. $\mathrm{K}$, by contrast, is enriched relative to seawater at depth at this and all the other sites we drilled. The initial depth $(\sim 17.7 \mathrm{mbsf})$ at which $\mathrm{K}$ increases is slightly deeper in Hole C0014G than in Holes C0014B and C0014D, consistent with other observations of hydrothermal fluid influence. This difference in depth implies that the thick pumice deposit in Hole C0014G acted as a barrier for the remixing of the phase-separated and phase-segregated hydrothermal fluids and kept them spatially stratified, with gas-rich fluid at shallower depths and brine-rich fluid at deeper depths, probably because of the difference in their relative density or buoyancy.

\section{Microbiology}

The maximum cell number was found just below the seafloor in Hole C0014B $\left(1.8 \times 10^{7}\right.$ cells $/ \mathrm{mL}$ at 0.33 mbsf), Hole C0014G (3.3 $\times 10^{7}$ cells $/ \mathrm{mL}$ at 0.27 mbsf), and Hole C0014D $\left(5.6 \times 10^{8}\right.$ cells $/ \mathrm{mL}$ at 0.23 mbsf). Cell numbers generally decrease with increasing depth, although there are some secondary peaks in biomass within shallower intervals in Holes C0014B and C0014D. Numerically abundant microbial communities at these shallow depths are not regarded as deep hot biosphere.

Microbial biomass at Site C00014 is generally similar to that found at Sites C0015 and C0017 and in a gravity core taken previously at Site C0014 (J. Ishibashi et al., unpubl. data). By contrast, the maximum microbial cell count in Hole C0014D is the highest we saw during Expedition 331. This densest microbial population was obtained from the $\mathrm{CH}_{4}$-enriched, sulfate-depleted sediments from just beneath the sulfate-enriched pumice layer. A second peak in microbial population in Hole C0014D was found in the sulfate-depleted sediments at 8.7 mbsf. All the microbial population peaks occur within $\mathrm{CH}_{4}$-enriched and sulfate-depleted layers, strongly suggesting the occurrence of functionally active anaerobic methane oxidizing (AMO) communities within the shallow subsurface.

Microbial populations in the deeper and hotter zones were numerically less abundant $\left(<1 \times 10^{5}\right.$ cells/ $\mathrm{mL}$ ). Overall, however, the microbial population at Site C0014 is more abundant than that at Site C0013.

Cultivation tests for Thermococcales (e.g., Thermococcus spp.), Aquificales (e.g., Persephonella spp.), and thermophilic Epsilonproteobacteria (e.g., Nitratiruptor spp.) produced no positive enrichment. Enrichment experiments for marine iron-oxidizing bacteria (FeOB) such as the Zetaproteobacteria (e.g., Mariprofundus ferrooxydans), however, showed limited growth within the uppermost $2 \mathrm{~m}$ of sediment, to be further investigated during shore-based research.

Fluorescent microspheres were used to check for contamination in cores taken with the HPCS, and perfluromethylcyclohexane (PFC) was used as a tracer for contamination in all cores. Fluorescent microspheres were not detected in most of the core samples from Site C0014, even within exterior parts of the core. High numbers of microspheres were detected in pumice layers, however, such as those sampled at 6.67 mbsf in Hole C0014D and 7.84 mbsf in Hole C0014G. Relatively high PFC tracer concentrations were also found at 40.6 and 43.8 mbsf in Hole C0014B, at 6.67 mbsf in Hole C0014D, and at 55.7 mbsf in Hole C0014G. Contamination by drilling fluids and/or by core disturbance would be difficult to avoid for such layers because of their high porosity and heavy fragmentation. Because such samples are important for hydrogeological controls on formation of subseafloor microbial communities, such samples need to be studied carefully in future research.

\section{Site C0015}

We spent only $9 \mathrm{~h}$ at Site C0015. Three holes were drilled (see Fig. F2 in Expedition 331 Scientists, 2011c), to a maximum depth of only 9.5 mbsf, but only two recovered core (Fig. F12). 
Despite the relatively short interval cored (0-9.5 mbsf), a broad diversity of sediment types was drilled at Site C0015: with coarse pumiceous gravel and grit, siliciclastic sands, hemipelagic mud, bioclastic gravel, and foraminiferal sediment all recovered. In order to be consistent with nomenclature applied to other sites drilled during this expedition, these interlayered sediments are grouped as a single lithostratigraphic unit.

Hydrothermal alteration is absent in the cored interval at Site C0015. With the exception of the interval from 3.2 to $5.07 \mathrm{mbsf}$ in Hole C0015B, the fine-grained sediment, sand, and pumiceous gravel recovered from the site shows weak oxidation. The interval from 3.2 to 5.07 mbsf in Hole C0015B comprises reduced olive-green mud with abundant biogenic fragments. This interval shows no evidence of oxidation. As is expected, very fine grained framboidal pyrite, likely to have been formed by biogenic processes, is found in trace quantities within this interval.

Interstitial water at Site C0015 is generally indistinguishable from seawater. Methane and hydrogen are very low and provide no evidence for hydrothermal input. Nevertheless, the microbial population is more abundant $\left(4.8 \times 10^{6}\right.$ to $1.2 \times 10^{7}$ cells $/ \mathrm{mL}$ sediment $)$ than at those sites that exhibit hydrothermal flow in the subseafloor. Over the entire depth interval cored (0-9.4 mbsf), the mud, sand, and pumiceous gravel show weak oxidation, expressed as a yellow to brown discoloration of the mud and orange to brown iron oxide staining on some pumice fragments. Scanning electron microscope (SEM) imaging of orange-brown botryoidal aggregates of Fe-Si oxyhydroxides shows a filamentous structure typical of oxyhydroxides. Subseafloor microbial communities at Site C0015 may thus be sustained by both organotrophic and Fe-oxidizing chemolithotrophic production. Indeed, enrichment experiments conducted at Site C0015, selecting for the growth of marine $\mathrm{FeOB}$, were successful for most samples to $\sim 9 \mathrm{mbsf}$, exhibiting cellular morphologies common for known iron oxidizers. FeOB communities are commonly found at low-temperature hydrothermal systems (Rassa et al., 2009), and further exploration of samples collected at Site C0015 will enhance our understanding of FeOB biodiversity.

\section{Site $\mathrm{C0016}$}

\section{Operational observation, stratigraphy, minerals, and physical properties}

Two holes were drilled at Site C0016 (see Fig. F1 in Expedition 331 Scientists, 2011d), but core was recovered from only one of them (Fig. F13). Hole C0016A was drilled with the BHI system, without a guide base, directly into the top of the $30 \mathrm{~m}$ high NBC hydrothermal sulfide mound that was thickly covered with galetheid crabs and was discharging fluid at temperatures as high as $311^{\circ} \mathrm{C}$. We spudded the hole at the crest of the mound within 1-2 $\mathrm{m}$ of a vent that was steadily and continuously phase separating, which made it look as if it was flaming. The drill bit penetrated easily and quickly. We noticed almost immediately that the drill string was canted by $10^{\circ}$, which made the pipe move erratically as it rotated and caused it to enlarge the top of the hole. That the drill pipe was listing $10^{\circ}$ from vertical was later attributed by the drillers to the effect of the Kuroshio Current. The designated $18 \mathrm{~m}$ of pipe was lowered within minutes at the rig floor, although we determined later that only $\sim 15 \mathrm{~m}$ actually went into the hole; the rest just added to the bowing of the drill string in the water column. When $18 \mathrm{~m}$ of pipe had been lowered (with $\sim 15 \mathrm{~m}$ of penetration), the drillers attempted to pull out of the hole. Two small steam explosions were seen around the pipe in the ROV video image, the flow of hot water and "black smoke" increased dramatically, and then the end of the pipe snapped off. The steam explosions were probably triggered by pressure transients induced by movement of the pipe in the hole in a fluid that was already on the verge of boiling. The drillers recorded a series of brief, sharp incidents of overpull that ended abruptly with the breaking of the pipe. A short section fell onto the mound and was recovered by the ROV, but the bit and most of the BHA stayed in the hole. The most likely explanation is that the pipe became bent in the hole, largely because of the stress put on it by rotating $10^{\circ}$ from the vertical, and then broke when it was pulled out vertically. For the pipe to bend, though, it must have encountered some hard material within the mound, most of which appeared to be very soft. According to the drillers, it is not likely that either the high temperature or the small steam explosions contributed to the break. The major cause appears to have been the $\mathrm{Ku}$ roshio Current, which caused the drill string to buckle and to deviate $10^{\circ}$ from vertical. The increase in black smoker flow that we observed with the ROV was almost certainly the result of our enlarging the orifice at depth, possibly by poking a larger hole into a cap rock that was inhibiting flow. This black smoker flow was still vigorous 1 day later but had diminished somewhat and become a clear, dark fluid 5 days after drilling. When first seen $>10$ y ago, the NBC vent site was emitting a clear, dark, single-phase fluid, which subsequently evolved to a boiling fluid. The fluid emitted since our drilling appears to resemble this earlier fluid, and so may have a different composition from that described by Kawagucci et al. (2011). 
Hole C0016B was again drilled with the BHI system, this time with a guide base. It was positioned at the foot of the NBC mound, immediately adjacent to it and $20 \mathrm{~m}$ west of the NBC vent and Hole C0016A. It penetrated to 45 mbsf in three runs of 9,18 , and 18 $\mathrm{m}$. Each run recovered several large pieces of core, but the total recovery was only $2.095 \mathrm{~m}$ (Fig. F13), nearly all of it hard rock. Hole C0016B was not cased, but it was fitted with a corrosion cap with $3 \mathrm{~m}$ of 5.5 inch pipe hanging beneath and extending 0.4 $\mathrm{m}$ into the seafloor. ROV video images showed vigorous black smoker discharge from the corrosion cap outlet immediately after its deployment. This hydrothermal emission began only after the third coring run, which penetrated $27-45 \mathrm{mbsf}$, and was probably derived from a depth below 38 mbsf (Fig. F13).

The overall core recovery was only $4.7 \%$ from Hole C0016B, consisting mostly of hard rock. The first core comprises two pieces of clastic-textured massive sulfide totaling $61 \mathrm{~cm}$, separated by $3 \mathrm{~cm}$ of semimassive sulfide and underlain by another $15 \mathrm{~cm}$ of highly silicified and mineralized volcanic material altered to illite/muscovite clay, which probably came from 6-9 mbsf. The massive sulfide ore contains $40 \%-60 \%$ sphalerite $(\mathrm{ZnS}), 10 \%-20 \%$ pyrite $\left(\mathrm{FeS}_{2}\right)$, and a few percent each of galena (PbS) and chalcopyrite $\left(\mathrm{CuFeS}_{2}\right)$. It closely resembles the classic "black ore" of the Kuroko deposits of Miocene age in Japan and represents the first time such ore has been recovered from an active hydrothermal system beneath the seafloor. The second core consists of three pieces of three different lithologies, totaling $31 \mathrm{~cm}$, from 9 to 27 mbsf: two pieces of altered, silicified, mineralized volcanic rock above and below an $11 \mathrm{~cm}$ piece of very coarsely crystalline, snow white anhydrite with a sphalerite-pyrite vein running along one side. The third coring attempt recovered $99.5 \mathrm{~cm}$ of quartz-chlorite-altered volcanic rock with abundant stockwork veining filled with quartz, chlorite, pyrite, and late anhydrite.

Despite an obvious clastic protolith, textures and relationships seen in thin section for the massive sulfide require that a significant proportion of the sulfide mineralization occurred via subseafloor precipitation, with at least some sphalerite precipitating into void space in the rock. Additionally, the sulfide and sulfate paragenesis of the samples shows an evolving system, with early sphalerite mineralization overprinted by pyrite and then chalcopyrite, as temperature increases, before a second sphalerite mineralizing event, as temperatures cool, and a final seawater influx, indicated by late coarse anhydrite. As far as can be ascertained from limited shipboard petrographic work, the underlying altered volcanic rocks at Site C0016 show a similar evolution to the massive sulfide. In all cases, anhydrite is among the last phases precipitated during alteration, as seawater penetrated into the waning system. Pyrite increases relative to sphalerite and illite/muscovite alteration gives way to chlorite-quartz with increasing depth and temperature.

\section{Microbiology}

Cultivation tests for Thermococcales (e.g., Thermococcus spp.), Aquificales (e.g., Persephonella spp.), and thermophilic Epsilonproteobacteria (e.g., Nitratiruptor spp.) produced no positive enrichment from any of the samples from Hole C0016B. We did detect PFC contamination on the surfaces of several core samples from Hole C0016B, from PFC added to the drilling fluid.

\section{Site $\mathrm{C} 0017$}

\section{Operational observation, stratigraphy, minerals, and physical properties}

Hole C0017D was the deepest (150.7 mbsf) of four holes drilled at Site C0017 (Fig. F14; see Fig. F1 in Expedition 331 Scientists, 2011e) and is located $1550 \mathrm{~m}$ east of the high-temperature vents. Based on its low heat flow, it was inferred to be a location of probable recharge of the hydrothermal system. We observed no evidence for discharge of water from any of these holes, but the concave-upward temperature profile we measured (Fig. F15) can be fit reasonably well with an exponential function $\left(r^{2}=0.92\right)$ and is consistent with overall downwelling, with distinct perturbations in the temperature gradient that suggest localized lateral flow that may be influenced by the variable lithologies we cored.

We measured temperature successfully at seven depths in Holes C0017B-C0017D over the interval from 18.3 to $150.7 \mathrm{mbsf}$; combined with the ocean bottom water temperature at the site of $4.87^{\circ} \pm$ $0.54^{\circ} \mathrm{C}(1 \sigma, n=8)$, our profile is defined by eight points. Six of the downhole measurements were made using the APCT3 temperature shoe on the HPCS. The seventh and deepest measurement, at $150.7 \mathrm{mbsf}$, was made in triplicate using three identical thermoseal temperature-sensitive strips with chemically impregnated beads for $75^{\circ}, 80^{\circ}, 85^{\circ}, 90^{\circ}$, and $95^{\circ} \mathrm{C}$ taped to the bottom outer surface of the plastic core liner. These beads were darkened and thus exposed at maximum temperatures of $85^{\circ}, 90^{\circ}$, and $90^{\circ} \mathrm{C}$ on the three strips, which we report as $90^{\circ}$ $\pm 5^{\circ} \mathrm{C}$. The APCT3 shoe recorded a temperature in excess of its maximum range of $55^{\circ} \mathrm{C}$ for this core (but did not burn up; we recovered the entire temperature record). Down to $\sim 50 \mathrm{mbsf}$, where we encountered a hard layer that is probably pumice (no core 
was recovered), temperature remains low, $<15^{\circ} \mathrm{C}$ (Fig. F15). Beneath this hard layer, temperature jumps to $25^{\circ}-39^{\circ} \mathrm{C}$ at $69-85 \mathrm{mbsf}$ and then appears to level off for a short interval, reaching only $44^{\circ} \mathrm{C}$ at $112 \mathrm{mbsf}$ before increasing nearly exponentially to $90^{\circ} \mathrm{C}$ at the bottom of Hole C0017D at 150.7 mbsf.

Material recovered from Site C0017 consists mainly of hemipelagic homogeneous mud, pumiceous sediment, and volcaniclastic-pumiceous mixed sand, without the obvious hydrothermal alteration seen at other sites. Based on sediment character and structure, major mineral composition, and the occurrence of microfossils, sediments recovered from the four holes drilled consist of three main sediment types: hemipelagic mud, coarse angular pumiceous gravel, and volcanic sands with erosional bases. These sediments and lithologies are similar to those of Unit I encountered at Sites C0014 and C0015. However, the unaltered sedimentary sequence drilled at Site C0017 is much more vertically extensive, and subdivision may be drawn on the basis of the relative predominance of hemipelagic mud or volcaniclastic sediments. This divides the stratigraphy at Site C0017 into four units, an upper unit (Unit I) dominantly composed of hemipelagic mud from 0 to 18.5 mbsf underlain by two units dominated by pumiceous gravel from 19.1 to 36.2 mbsf (Unit II) and 61.1 to 78.8 mbsf (Unit III). The interval from 36.1 to $61.1 \mathrm{mbsf}$ was not cored, so it was not possible to group Unit II and Unit III as a single unit, despite the strong sedimentological similarity between them. Additionally, no core was recovered in the interval from 78.8 to $94.3 \mathrm{mbsf}$. The deepest portion of the cored interval, from 94.3 to 144.7 mbsf (Unit IV), is dominated by hemipelagic mud. The thicknesses of individual beds of mud and gravel at Site C0017 are significantly greater than those at Site C0014, consistent with the location of Site C0017 on the downthrown side of a normal fault.

Different lithologies of widely varying porosity and permeability alternate within the uppermost $37 \mathrm{mbsf}$ at Site C0017. In particular, the pumiceous gravel and sand layers are much more permeable than the hemipelagic mud layers (Unit I). As such, they represent potential pathways for recharge of cold bottom seawater into the hydrothermal system. One such example is the prominent oxidized interval from 26 to $35 \mathrm{mbsf}$ in Hole C0017C. These observations and inferences are consistent with the low thermal gradient in the shallow subseafloor and the concave-upward temperature profile that increases exponentially with depth. Similar lithologies occur over the depth interval 60-100 mbsf, with high porosity and permeability and a lower thermal gradient, suggesting the possibility of further recharge within this deeper interval. No core was recovered between 37 and 60 mbsf, but the drilling record indicates the presence of a hard layer at $\sim 50 \mathrm{mbsf}$ that could represent a hydrologic barrier between upper and lower permeable zones. At greater depth, the only hydrothermal alteration evident at Site C0017 was seen in the deepest core recovered, from 140-150 mbsf, where more permeable pumiceous grit horizons are partially altered to pale gray clay, although there is little change apparent in XRD-determined mineralogy, other than the addition of sylvite $(\mathrm{KCl})$ in one sample, which corresponds to the increase in pore water $\mathrm{K}$ at the base of Hole C0017D. The pale altered grit is intercalated with apparently unaltered indurated dark gray calcareous clay, again suggesting that the coarser sediment layers acted as flow paths. As noted above, the temperature at this depth is $90^{\circ} \pm$ $5^{\circ} \mathrm{C}$.

As was observed in Unit I at Site C0014, abundant foraminifers and coccoliths dominated by Emiliania huxleyi, Gephyrocapsa oceanica, and Reticulofenestra asanoi were identified within the upper 28 mbsf. Biostratigraphy thus supports the equivalence of Units I-IV at Site C0017 with Unit I at Sites C0014 and C0015.

\section{Interstitial water chemistry}

A total of 21 whole-round samples were processed at Site $\mathrm{C} 0017$ from four different holes. No samples were obtained between 30 and 63 mbsf. At $0-15$ mbsf, the interstitial water profiles show the clear effect of microbial sulfate reduction utilizing organic matter in the sediment: sulfate decreases slightly and alkalinity, ammonium, and phosphate increase with depth from 0 to 15 mbsf. From 15 to 30 mbsf, however, all of these chemical species reverse direction and return to seawater concentrations, indicating a source of unaltered seawater at $\sim 30 \mathrm{mbsf}$. This source can be identified as the oxidized layer at 26-35 mbsf discussed above, which is almost certainly a permeable layer through which seawater is flowing laterally, recharging the hydrothermal system $1550 \mathrm{~m}$ to the west. This layer presumably outcrops a short distance to the east.

Except for sulfate, the major ions are present over the depth interval 0-30 mbsf at seawater concentrations. Below 64 mbsf, however, $\mathrm{K}$ decreases to a low of $6.5 \mathrm{mM}$ at $106 \mathrm{mbsf}$ before rebounding again to the seawater value in the deepest sample from 141 mbsf. Over this same interval, Ca increases more or less steadily to $18 \mathrm{mM}$ and alkalinity to $6 \mathrm{mM}$. Changes in other ions are small or nonexistent. The causes of these changes are not obvious. The increase in $\mathrm{Ca}$ and alkalinity may result in part from dissolution of $\mathrm{CaCO}_{3}$, but this compound should become less soluble with rising temperature, which increases 
from $25^{\circ}$ to $90^{\circ} \mathrm{C}$ between 69 and 151 mbsf. $\mathrm{K}$ is typically taken up from seawater into clay minerals and zeolites at temperatures below $\sim 150^{\circ} \mathrm{C}$, but the abrupt rebound in $\mathrm{K}$ to the seawater value that occurs between 131 and 141 mbsf is hard to explain except by another permeable layer providing relatively unaltered seawater to that depth. It would have to do so without affecting the relatively more reactive species $\mathrm{Ca}$ and alkalinity.

Concentrations of methane and hydrogen are low and show no evidence for significant input from either hydrothermal processes or a prosperous anaerobic microbial community. Methane increases slightly near the bottom of the deepest Hole C0017D, probably from microbial methanogenesis at greater depth.

\section{Microbiology}

The maximum cell number was found within the mud of Unit I at $6.36 \mathrm{mbsf}\left(3.2 \times 10^{7}\right.$ cells $\left./ \mathrm{mL}\right)$, and a relatively abundant microbial population $(2.4 \times$ $10^{7}$ to $3.2 \times 10^{7}$ cells $/ \mathrm{mL}$ ) was identified above 10.8 mbsf. At greater depths, cell numbers generally decreased, although we found a substantial population at $20-40 \mathrm{mbsf}$, within the layer of lateral recharge identified by the oxidized sediment and the return of the interstitial water to seawater composition. This microbial community may thus be energized by iron oxidation under oxidative chemical conditions. Enrichment for FeOB in this zone of lateral recharge showed growth under microaerophilic conditions only. This represents the deepest enrichment of putative $\mathrm{FeOB}$ below the seafloor found to date, though caution is advised, as samples obtained by drilling may be contaminated.

Cultivation tests produced no positive enrichment for any samples from Site C0017, except for those enrichments conducted for the FeOB. Contamination tests found no fluorescent microspheres in most samples, even within exterior parts of core, at Site C0017. Contamination evaluated by PFC introduced into the drilling fluid was low even for unconsolidated pumice samples, and even at the surfaces of cores consisting mainly of pumice. We did find low levels of PFC in the interior of one core from Hole C0017D taken by the ESCS, but even there the concentration of PFC was much lower than in the drilling mud.

\section{Principal results}

\section{Lithostratigraphy}

The geological setting for Expedition 331 is highly complex and dynamic, recording a constantly changing interplay of pelagic and volcaniclastic sedi- mentation, gravity, and seismically triggered reworking, volcanism, faulting, and hydrothermal alteration and mineralization. In such an environment lithostratigraphic correlation is difficult, with many, if not all, lithological units having limited areal extent. Indeed, the most distinctive lithological units seen in material recovered during Expedition 331 are inherently difficult to correlate between sites: coarse pumiceous gravel typically forms lenticular bodies, which commonly vary by orders of magnitude in thickness over distances of a few tens of meters; massive sulfide mineralization is by definition highly localized around discrete sites of hydrothermal venting; and anhydrite precipitation is strongly controlled by temperature and subsurface hydrology, both of which have been demonstrated during Expedition 331 to vary rapidly, both spatially and temporally, at Iheya North. Given this complexity, it is not feasible to attempt to correlate lithostratigraphy between the sites drilled during the expedition, other than in the grossest sense, although detailed geochronological, isotopic, mineralogical, micropaleontological, and geochemical postcruise work may allow more detailed correlation in the future.

Broadly speaking, the entire sequence drilled at Sites C0014, C0015, and C0017 may be considered to belong to the same sequence of mixed volcaniclastic and pelagic sediments, with the first site showing significant hydrothermal alteration of the sequence. Similarly, Units I-III at Site C0013 belong to this same sedimentary sequence, with an extremely strong hydrothermal overprint. The interval drilled at Site C0016 may reasonably be considered to represent volcanic basement underlying the sediments, so is older than these sequences. Unit IV at Site C0013 may also be equivalent to the Site C0016 rocks, although recovery issues in the deeper drilling at Site C0013 make it difficult to determine with any certainty that volcanic basement has been drilled at the site.

\section{Biostratigraphy}

The active hydrothermal discharging Site C0016 and the nearby Site C0013 did not have microfossils in any of the core catcher samples, even those from 0 to 10 mbsf. At Site C0014, which has a moderate temperature gradient of $3^{\circ} \mathrm{C} / \mathrm{m}$ within the uppermost 50 mbsf, microfossils were found only within the uppermost $6.5 \mathrm{mbsf}$. Microfossils were present throughout the sediment at Site C0015 with two particularly foraminifer rich layers at $\sim 3$ mbsf. Recharge Site C0017 yielded microfossils from two depths: 9-28 mbsf, at $<6^{\circ} \mathrm{C}$, and $112 \mathrm{mbsf}$, at a measured temperature of $44^{\circ} \mathrm{C}$. In all cases, major microfossils are modern assemblages of planktonic foraminifers. Hydro- 
thermal activity is deleterious both to growth of benthic foraminifers and to the preservation of microfossils, especially coccoliths, which were found rarely and were invariably badly corroded. Some foraminifer tests in near-surface samples from Sites C0014 and C0017 were exquisitely replaced by micrometer- and submicrometer-scale pyrite, so accurately that species could be determined.

Iron oxides in near-surface samples from Site C0015 possess micrometer-diameter, filamentous organic coatings and need to be assessed using high-resolution imaging for the presence of bacterial microfossils.

\section{Petrology}

Interpretation of hydrothermal alteration and mineralization for Sites C0013-C0017 provides a broad overview of the nature, evolution, and architecture of the Iheya North hydrothermal system.

Site C0016 at NBC mound, despite very poor recovery overall, intersected massive sphalerite-rich sulfides, thus recovering for the first time, from beneath an active seafloor hydrothermal system, material that strongly resembles the black ore of the Kuroko deposits of Miocene age in Japan. Despite an obvious clastic protolith, the textures and relationships seen in thin section for the massive sulfide require that a significant proportion of the sulfide mineralization occurred via subseafloor precipitation, with at least some sphalerite precipitating into void space in the rock. Additionally, the sulfide and sulfate paragenesis of the samples shows an evolving system, with early sphalerite mineralization overprinted by pyrite and then chalcopyrite, as temperature increased, before a second sphalerite mineralizing event, as temperatures cooled, and a final seawater influx, indicated by late coarsely crystalline anhydrite.

The underlying altered volcanic rocks recovered at Site C0016 show a similar evolution to the massive sulfide. The silicified volcanic rock from Core 331C0016-1L shows similar sulfide paragenesis and, in all cases, anhydrite was among the last phases precipitated during alteration.

With increasing depth at Site C0016, the relative abundance of pyrite increases with respect to sphalerite, both on a local scale within the massive sulfide recovered in Core 331-C0016-1L and overall within the sequence. This variation is one that is observed in many volcanic-hosted massive sulfide (VHMS) mineral systems and is interpreted to be a function of increasing temperature with depth. The predominance in Hole C0016B of quartz-muscovite/illite alteration grading to quartz-chlorite alteration at depth is also consistent with the proximal quartz- white mica grading to chloritic alteration commonly recorded in the immediate footwall of ancient VHMS systems, including the Miocene Kuroko deposits of Japan.

At Site C0013, a likely location of recent high-temperature discharge, sediments exhibit kaolinite-muscovite alteration and contain variable thicknesses of sulfide-rich material to $\sim 5$ mbsf. Native sulfur is also abundant near-surface, which, together with the abundance of kaolinite, suggests acidic fluids, probably caused by oxidation of $\mathrm{H}_{2} \mathrm{~S}$ dissolved in hydrothermal fluid or released from the fluid during decompression. Below $\sim 5 \mathrm{mbsf}, \mathrm{Mg}$ chlorite and anhydrite are the dominant alteration phases to 26 mbsf, at which depth a hard sequence of volcanic breccias altered to quartz and $\mathrm{Mg}$ chlorite with scattered quartz veins was intersected; we interpret this sequence to represent volcanic basement. This lithology extends to the bottom of the deepest Hole C0013E at the site, at 54.5 mbsf.

The transition from kaolinite-muscovite-rich to chlorite-rich rocks with increasing depth at Site C0013 is similar to the gradation from paragonitized to chloritized rocks that was documented for the basement underneath the TAG hydrothermal mound at the Mid-Atlantic Ridge $\left(26^{\circ} \mathrm{N}\right)$ (Humphris et al., 1995). The difference in mineralogy between Iheya North Knoll and the Mid-Atlantic Ridge can be attributed to the lack of iron and the abundance of potassium available within the felsic volcanic rocks in the Okinawa Trough when compared with the mafic volcanic rocks of the mid-ocean-ridge setting. Although it is difficult to estimate alteration temperatures from clay and phyllosilicate mineralogy, transitions seen at Site C0013 are consistent with temperatures of $\sim 150^{\circ}-200^{\circ} \mathrm{C}$ for the uppermost kaolinite-bearing sequence and $\sim 220^{\circ}-300^{\circ} \mathrm{C}$ for the $\mathrm{Mg}$ chlorite-rich sediments and rocks below $\sim 5$ mbsf.

The latest alteration phase seen at Site C0013 is coarse-grained anhydrite in veins, which overprint both kaolinite-muscovite and $\mathrm{Mg}$ chlorite alteration between $\sim 4$ and $\sim 10$ mbsf. This anhydrite likely precipitated when downwelling seawater mixed with upwelling hydrothermal fluid as the system waned, at a temperature of $\sim 150^{\circ} \mathrm{C}$.

Hydrothermal alteration at Site C0014 shows a change, with increasing depth, from illite/montmorillonite-bearing to $\mathrm{Mg}$ chlorite-bearing rocks at 25-30 mbsf. This alteration is similar to the change from kaolinite-muscovite to $\mathrm{Mg}$ chlorite alteration observed at Site C0013. Mg chlorite implies alteration temperatures of $\sim 220^{\circ}-300^{\circ} \mathrm{C}$, which is broadly consistent with the current temperature data at Site C0014. 
When compared to Site C0013, the relative predominance of illite/montmorillonite, rather than kaolinite, at Site C0014 and the absence of native sulfur at Site C0014 imply higher fluid $\mathrm{pH}$ for the altered sequence at Site C0014, consistent with an absence of the high-temperature $\mathrm{H}_{2} \mathrm{~S}$-rich fluids that form sulfide chimneys in the Okinawa Trough.

Significantly, transitions in alteration mineralogy occur at much greater depths at Site C0014 than at the more proximal Site C0013, consistent with the lower temperature gradient observed at the more distal site. Anhydrite is present at depths $>57$ mbsf in Hole C0014G, mostly in millimeter-scale irregular veinlets with halite but in much lower abundance than was seen at Site C0013. Primary volcanosedimentary mineralogy is also partially preserved throughout the altered sequence at Site C0014, implying a significantly lower fluid flux than that at Site C0013. Pyrite occurs only at extremely low abundances, mostly as fine-grained disseminations and very rare millimeter-scale veinlets throughout the sequence. These observations are consistent with the interpretation that Site C0013 represents a site of recent high-temperature discharge, whereas Site C0014 is a "background" location within the hydrothermal system at Iheya North.

At Site C0017, there is little evidence of hydrothermal alteration, other than a zone from $\sim 26$ to 35 mbsf that shows weak to moderate oxidation within the otherwise reduced sedimentary sequence. Geochemical results indicate that this zone of oxidation is the result of an influx of seawater at this depth, potentially representing recharge flow into the Iheya North hydrothermal system.

Hydrothermal alteration is absent in the shallow (maximum depth $=9.4 \mathrm{mbsf}$ ) cored interval at Site C0015. With the exception of the interval from 3.2 to 5.07 mbsf in Hole C0015B, fine-grained sediment, sand, and pumiceous gravel recovered from the site show weak oxidation. The interval from 3.2 to 5.07 mbsf in Hole C0015B comprises reduced olive-green mud with abundant biogenic fragments. This interval shows no evidence of oxidation. As is expected, very fine grained framboidal pyrite, likely to have been formed by biogenic processes, is found in trace quantities within this interval.

\section{Geochemistry}

Site C0016, drilled directly into and immediately adjacent to a major high-temperature hydrothermal mound of the Iheya North hydrothermal field, NBC mound, yielded no samples suitable for interstitial water or headspace gas analyses. Such samples were recovered from Sites C0013 and C0014, drilled, re- spectively, 160 and 450 m east of the high-temperature vents, and they clearly show the chemical signatures of high-temperature fluid-rock interaction.

Depth profiles for $\mathrm{CH}_{4}$ and $\mathrm{H}_{2}$ show different patterns at Site C0013: methane is most enriched at 1012 mbsf, whereas $\mathrm{H}_{2}$ increases with depth. The peak in methane combined with a consistently high ratio of methane to ethane suggests an input of hydrothermal fluid that already contains unusually high concentrations of microbially produced methane. The $\mathrm{CH}_{4}$ maximum occurs just beneath a cap rock layer and is consistent with the observed flow of hydrothermal fluid up the hole. The logarithmic increase in hydrogen with depth suggests a deep source for this gas, as well as a relatively shallow sink at $\sim 10$ mbsf that is probably microbial consumption. Total sulfur content of the sediment varies from $1 \%$ to $66 \%$ and is highest within the uppermost $10 \mathrm{mbsf}$. Total organic carbon and total nitrogen are generally both quite low, $<0.2$ and $<0.02 \mathrm{wt} \%$, respectively, although there are a few high values that cannot be attributed to melting of the plastic core liners. These liners melted at depths as shallow as 12.5 mbsf, indicating that the temperature at this depth well exceeded the $82^{\circ} \mathrm{C}$ found to be the deformation temperature in tests done shipboard. It appears that hydrothermal alteration and possibly also microbial activity remineralize sedimentary organic carbon relatively quickly.

Site C0013 interstitial water is heavily affected by the abundant anhydrite in the core, which partially dissolved prior to separation of the pore water, greatly increasing $\mathrm{Ca}$ and sulfate in solution; the increased $\mathrm{Ca}$, in turn, displaced $\mathrm{K}$ and $\mathrm{Mg}$ from ion exchange sites in clay minerals in the sediment. Chloride varies from $34 \%$ lower than the seawater value to $12 \%$ higher in the deepest pore water sample from the site, from Hole C0013E at 17 mbsf, almost certainly because of phase separation. This deepest sample is a relatively pure hydrothermal fluid, containing only $7 \mathrm{mM} \mathrm{Mg}$ and $13 \mathrm{mM}$ sulfate; a $\mathrm{Na} / \mathrm{Cl}$ ratio $10 \%$ lower than that in seawater, indicating uptake of $\mathrm{Na}$ into alteration minerals; and elevated $\mathrm{Cl}(623 \mathrm{mM})$, $\mathrm{Ca}(48 \mathrm{mM}), \mathrm{K}(81 \mathrm{mM}$, among the highest values ever measured in a seafloor hydrothermal system), alkalinity $(22 \mathrm{mM})$, and ammonium $(1.5 \mathrm{mM})$.

At Site C0014, concentrations of dissolved sulfate and methane are inversely correlated, especially above 30 mbsf. Variable (Hole C0014B) and low (Hole C0014G) methane concentrations in the upper section indicate zone(s) of anaerobic methanotrophy at the sulfate-methane transitions. The observed high methane to ethane ratios further suggest that methane at this site is mainly biogenic. Tempera- 
tures within the deeper horizons, which exceed $55^{\circ} \mathrm{C}$ at only $16 \mathrm{mbsf}$ and $210^{\circ} \mathrm{C}$ at $50 \mathrm{mbsf}$, would seem to preclude in situ methanogenesis, however. Biogenic methane could be migrating downward from the biologically active zone, or the observed methane at depth (Hole C0013G) could be a component of the subseafloor hydrothermal fluids.

Interstitial water at Site C0014 shows large variations in composition both laterally and vertically as a result of hydrothermal input. At 0-10 mbsf, it closely resembles seawater, except for sulfate, alkalinity, and the nutrient species, which are affected by microbial sulfate reduction and show large lateral variation from hole to hole. Below $10 \mathrm{mbsf}$, it deviates sharply from seawater, with generally deceasing sulfate, $\mathrm{Mg}$, and $\mathrm{Na} / \mathrm{Cl}$ and increasing $\mathrm{Ca}, \mathrm{K}$, and Si. Chloride varies from that of seawater in the uppermost $27 \mathrm{mbsf}$ to a vapor at $27-40$ mbsf and a brine at $40-114$ mbsf. These large lateral and vertical variations display the role of permeable and less permeable layers in the sediment in permitting and isolating lateral flow of hydrothermally influenced waters.

Interstitial water at Site C0015 is generally indistinguishable from seawater. Methane and hydrogen are very low and provide no evidence for hydrothermal input.

At hydrothermal recharge Site C0017, 1550 m east of the hydrothermal vents, concentrations of methane and hydrogen are low and show no evidence for significant input from either hydrothermal processes or a prosperous anaerobic microbial community. Methane increases slightly near the bottom of the deepest Hole C0017D, probably from microbial methanogenesis at greater depth. As at Sites C0013 and C0014, interstitial water at Site C0017 shows the effects of lateral flow of water through permeable layers, but at this site it is unaltered seawater, through a layer of oxidized pumice at 26-35 mbsf and possibly through deeper layers as well. As at Site C0014, pore water within the uppermost sediments, at 0-15 mbsf, is affected by microbial reduction of sulfateutilizing organic matter. At greater depth, concentrations generally return to those in seawater because of lateral recharge, probably from an outcrop of pumice to the east. Chloride increases slightly with greater depth along with $\mathrm{Ca}$ and alkalinity, and $\mathrm{K}$ decreases and then increases again to nearly the concentration in seawater in the deepest sample collected, from 141 mbsf.

\section{Microbiology}

We did not obtain immediate evidence of an active deep hot biosphere during Expedition 331. We did, however, firmly establish the hydrogeologic basis for a variety of subseafloor microbial habitats associated with a high-temperature hydrothermal system. We also conducted the first tests for contamination by drilling fluid using PFC as a tracer with a variety of drilling and coring systems. We found that, in general, these systems on the Chikyu can collect core that is free of contamination and therefore useful for microbial studies.

Two of the five sites we drilled, Sites C0015 and C0017, hosted relatively abundant subseafloor microbial populations, but these depended on buried sedimentary organic matter. Even at these two sites, the microbial cell abundance was much lower than those found previously at Ocean Drilling Program (ODP)/IODP sites along continental margins (Parkes et al., 1994, 2000; D'Hondt et al., 2004), even though the Iheya North hydrothermal field is located in a backarc basin along a continental margin. These low cell abundances presumably result from the relatively low total organic carbon in the sediments, generally $<0.1 \mathrm{wt} \%$ at Site C0015 and $<0.5$ $w t \%$ at Site C0017. The abundant occurrence of very permeable layers of pumice and volcaniclastic sediments and the consequent recharge of seawater into the hydrothermal system at Site C0017 generates a locally highly oxic subseafloor environment. This environment promotes the formation of oxidative oligotrophic and/or chemolithoautotrophic microbial communities, rather than obligately anaerobic communities including fermentors, methanogens, and sulfate reducers. Methane concentrations at Sites C0015 and C0017 are generally low, and microbial methanogenesis is quite unlikely. Instead, we found layers enriched in iron oxide minerals at these two sites, which were probably produced by aerobic to anaerobic subseafloor microbial communities sustained by oligotrophic and chemolithoautotrophic iron oxidizers such as Zetaproteobacteria (Emerson et al., 2007). Successful enrichments of putative FeOB from these two sites will allow us to investigate the relationships of these subseafloor microbial communities.

The other three sites we drilled, Site C0016 at an active hydrothermal mound and Sites C0013 and C0014 about 160 and $450 \mathrm{~m}$ to the east, all had very high temperatures at very shallow depths, limiting microbes to the uppermost part of the sediment column, if they were present at all.

\section{Physical properties and downhole temperature measurements}

Physical properties from the MSCL system as well as discrete measurements of density and porosity, thermal conductivity, formation factor, $P$-wave velocity, and in situ temperature were made at the five sites drilled during Expedition 331. Sediment was cored at 
Sites C0013, C0014, C0015, and C0017. The major sediment types are pelagic and hemipelagic mud and volcaniclastic deposits, variably altered by hydrothermal processes including silicification and precipitation of anhydrite. At Site C0016 only rocks were recovered, including massive sulfide and sulfate and altered and mineralized volcanic breccia and flows.

At Site C0013, there is evidence from the density, thermal conductivity, and $P$-wave velocities within the uppermost 12 mbsf for hard layers rich in anhydrite, interbedded with softer layers. A hard volcanic layer was penetrated at 22 mbsf. At Site C0014, physical property results are similar in the surface portions of all seven holes, and density and porosity are consistent with pumiceous sediments. At greater depths at Site C0014, sediments become more consolidated, as evidenced by higher thermal conductivity, lower porosity, and higher formation factor, but no clear evidence for a hard basement layer is seen until possibly in our deepest sample, from 128 mbsf. Temperature was measured four times in four different holes at Site C0014 using the APCT3 shoe, yielding values between $16^{\circ}$ and $22^{\circ} \mathrm{C}$ at $4-9$ mbsf and $\sim 55^{\circ} \mathrm{C}$ at 16 mbsf. Thermoseal strips were used three times in Hole $\mathrm{C} 0014 \mathrm{G}$ and measured $>120^{\circ} \mathrm{C}$ at 38 mbsf, $145^{\circ} \mathrm{C}$ at $47 \mathrm{mbsf}$, and $>210^{\circ} \mathrm{C}$ at $50 \mathrm{mbsf}$. At Site C0015, physical properties are relatively constant to the maximum depth of 9 mbsf. There is a slight increase in bulk density and a corresponding decrease in thermal conductivity toward the bottom of the hole that coincide with the presence of sandy layers. At Site C0017, the uppermost 20 mbsf exhibits fairly uniform physical properties consistent with the presence of clay; between 20 and 40 mbsf the density and porosity reflect a higher percentage of pumice in the sediments. The in situ temperature at $37 \mathrm{mbsf}$ is $6^{\circ} \mathrm{C}$. Between 70 and $90 \mathrm{mbsf}$ at Site C0017, thermal conductivity and bulk density increase along with pumice content, whereas temperature increases from $25^{\circ}$ to $40^{\circ} \mathrm{C}$. In the lower portion of Hole C0017D, at 95-148 mbsf, thermal conductivity, bulk density, and formation factor all increase with depth, consistent with the presence of increasingly indurated clay. At the maximum depth drilled of $151 \mathrm{mbsf}$, the temperature is $90^{\circ} \pm 5^{\circ} \mathrm{C}$, as measured in triplicate with thermoseal strips.

\section{Preliminary scientific assessment}

\section{Artificial hydrothermal vents created}

A total of 24 holes were drilled during Expedition 331 , of which 21 recovered core. We drilled $708 \mathrm{~m}$ and recovered $312 \mathrm{~m}$ of core from $560 \mathrm{~m}$ attempted, yielding an overall recovery of 56\%. This compares highly favorably with the only other attempt to drill a submarine felsic-hosted hydrothermal system during ODP Leg 193, which recorded an overall core recovery of $10.7 \%$ at the PACMANUS site in the Eastern Manus Basin, Papua New Guinea (Shipboard Scientific Party, 2002). Holes C0013E and C0014G were cased with stainless steel pipe and capped with stainless steel corrosion caps with open outlets, and Hole C0016B was capped but not cased above a $3 \mathrm{~m}$ insertion pipe. Four artificial hydrothermal vents were created by our drilling operations, in Holes C0013E, C0014G, C0016A, and C0016B, in which hydrothermal fluid formerly trapped in the subseafloor ascended up the hole and exited into the ocean (Fig. F9). All hydrothermal vent emissions were confirmed to be $>240^{\circ} \mathrm{C}$ using thermoseal strips taped to the outlet pipe of the corrosion cap. These newly created hydrothermal vents will serve as windows into the subseafloor and any associated microbial communities entrained into them in postdrilling, longterm monitoring studies of fluid composition and flow and of in situ microbial colonization.

\section{Subseafloor hydrothermal alteration, fluid flow, and reservoirs within the defined hydrogeologic structure}

Drilling and coring operations during Expedition 331 provide insight into the hydrothermal flow regime at Iheya North Knoll. Although the thermal gradient was known to be high at Site C0016 at NBC mound, Sites C0013 and C0014 have steeper thermal gradients than we expected.

Site C0013 is located $160 \mathrm{~m}$ east of the vigorous high-temperature vents and mounds. On our third coring attempt in Hole C0013C, the core liner melted, indicating a temperature $>82^{\circ} \mathrm{C}$ at $12.5 \mathrm{mbsf}$. Immediately on penetrating a cap rock just a few meters below the seafloor, hot hydrothermal fluid began to flow from Hole C0013E. Drilling to our maximum depth of $54.5 \mathrm{mbsf}$, we penetrated several hard, low-porosity layers that could function as a cap rock and found thick, porous sediment hydrothermally altered at high temperature between the harder, less permeable layers. The interstitial water showed large changes in composition both laterally and vertically over short distances, suggesting chaotic lateral flow in permeable horizons separated by impermeable barriers. The lithostratigraphy, physical properties of the sediment and rock, and interstitial water chemistry thus all provide insight into the hydrothermal flow regime at Site C0013. These results are, in turn, broadly consistent with the seismic reflection struc- 
ture, which shows strong reflectors connecting several of the sites at very shallow depths or at depths greater than the drilled interval (Fig. F5).

Site C0014 is located $\sim 450$ east of the high-temperature vents and mounds. Even here we found that the temperature exceeds $210^{\circ} \mathrm{C}$ at only $50 \mathrm{mbsf}$. The temperature gradient is roughly linear from 0 to 47 mbsf, increasing from the bottom water temperature of $4.5^{\circ}$ to $145^{\circ} \mathrm{C}$ over that depth range, but it deviates greatly from this line at $0-9$ and $47-50 \mathrm{mbsf}$, where it is clearly affected by high-temperature fluid pooling or lateral flow. Interstitial water chemistry demonstrates vertical stratification, from water of seawater chloride values at 0-25 mbsf to a vapor at 29-38 mbsf and a brine from 48 mbsf to the deepest sample at 114 mbsf. Within the upper sediments, which consist of pelagic sediments and pumiceous gravel, there is considerable lateral variability in the intensity of microbial sulfate reduction utilizing organic matter between the four holes that are only meters apart; clearly there is a functionally prosperous and metabolically diverse subseafloor biosphere here. At $20 \mathrm{mbsf}$, where the temperature is $\sim 70^{\circ} \mathrm{C}$, and to the bottom of the deepest Hole C0014G at 137 mbsf, where a linear fit would have the temperature exceed $400^{\circ} \mathrm{C}$, the sediment and rock we recovered is intensely hydrothermally altered. As at Site C0013, chaotic flow must be occurring through permeable formations and along fault structures, and is likely separated vertically by impermeable beds that behave as cap rocks. Again as at Site C0013, the seismic reflection structure at Site C0014 is generally compatible with the lithostratigraphic and hydrogeologic architecture we infer from drilling.

Site C0016 is located on and immediately adjacent to the NBC high-temperature hydrothermal mound and vents. We did not recover sufficiently continuous core at this site to determine a detailed lithostratigraphy. We did recover both massive and stockwork sulfide ores, as discussed below.

Site C0017 is located $1550 \mathrm{~m}$ east of the high-temperature vents of the Iheya North hydrothermal field, in an area of low heat flow. The overall temperature profile is exponential and concave upward, consistent with downwelling of cold water, implying that this is an area of recharge to the hydrothermal system. We reached a maximum temperature of $90^{\circ}$ $\pm 5^{\circ} \mathrm{C}$ at the bottom of the deepest Hole C0017D at 151 mbsf. Deviations from a smooth temperature profile indicate the presence of a discrete zone of cold water recharge, consistent with interstitial water chemistry and the presence of a highly oxidized layer at 26-35 mbsf that supports a microbial community. We found only a small amount of hydrothermally altered sediment deep in Hole C0017D.
These results, taken together, provide a more detailed look at the large-scale hydrogeology of the Iheya North Knoll hydrothermal system than has typically been available for subseafloor hydrothermal systems elsewhere, sketched in Figure F16. The hydrological regime at Iheya North Knoll is characterized by largescale hydrothermal alteration, deposition, and fluid migration within permeable rocks and sediments hosted by the Iheya North Knoll volcanic complex. Prior to Expedition 331, we knew little about the spatial and temporal scales and patterns of hydrothermal circulation in subseafloor hydrothermal systems, particularly those in subduction zone settings such as volcanic arcs and backarc spreading centers. Postcruise studies of data and samples recovered during Expedition 331, along with future field investigations that will benefit from the cased and capped holes we left, will further our understanding of these important hydrothermal systems.

\section{Stratification of hydrothermal fluid by subseafloor phase separation and segregation}

Interstitial water collected during Expedition 331 demonstrates that the Iheya North Knoll hydrothermal field is chemically stratified with respect to chloride concentration. Pore water near the seafloor has the chloride concentration of seawater. It is underlain by a thin and possibly discontinuous vapor-rich layer that has lower chloride than seawater at $5 \mathrm{mbsf}$ and deeper at Site C0013 and at 29-38 mbsf at Site C0014. Beneath the vapor-rich layer lies a chlorideenriched brine, at least to the maximum depth of the holes drilled at these two sites. The recharge Site C0017 has no statistically convincing indication of a low-chloride layer. Previous surveys of the Iheya North hydrothermal vents have always found that the discharging fluids are low in chloride and vapor rich (Kawagucci et al., 2011; Takai and Nakamura, 2010). It has been a puzzle where the complementary brines may reside. Several theoretical calculations have predicted that the greater densities of brines cause them to sink to greater depths within subseafloor hydrothermal reservoirs (Fontaine and Wilcock, 2006). Until now there has been no observational evidence to support this hypothesis. Expedition 331 provides tentative evidence of subseafloor stratification of hydrothermal fluids that have phase separated. More evidence is needed, and we will monitor this process in the future using the hydrothermal fluids discharging from the artificial vents.

\section{Is a subvent biosphere present?}

So far, the shipboard analyses and experiments have provided little evidence for the existence of a hot 
subvent biosphere beneath the Iheya North hydrothermal field, though cultivation from a colder, diffusely venting site and a site of lateral recharge provided evidence for a subvent iron-oxidizing microbial community. Prior to this expedition, it was hypothesized that subseafloor mixing between hydrothermal fluids and recharging seawater was sustained by a fine-scale network of narrow hydrothermal fluid flow paths within the subseafloor along the eastern flank of the hydrothermal system. The hydrothermal features we intersected by drilling, including the permeable reservoirs and flow paths, appear to be larger in scale that we had envisioned. Most of the sediment and rock we cored at Sites C0013, C0014, and C0016 have been exposed to much higher temperatures than the microbiologically habitable temperature range $\left(<150^{\circ} \mathrm{C}\right)$. Smaller and more limited zones that are habitable by $\mathrm{mi}$ crobes were sampled, however, as well as one large one, the hydrothermal recharge zone at Site C0017. Recharge zones are, of course, an essential part of all hydrothermal systems. Future shore-based, more detailed investigations by a team of international and interdisciplinary scientists will provide multiple lines of evidence for the functionally active, metabolically diverse subseafloor microbial communities that live within the environments of the Iheya North hydrothermal system.

\section{Actively forming Kuroko deposit in the subseafloor environment of the Iheya North field}

Much of the sediment and rock we cored at Sites C0013, C0014, and C0016 was intensely hydrothermally altered, and mineralized. Exceptional among the disseminated and vein, stockwork-type sulfide we recovered is the massive sphalerite-rich ore we cored in Hole C0016B. This marks the first time this type of massive sulfide, which closely resembles the Kuroko black ore, has been recovered from an active deep-sea hydrothermal system. We recovered only $2.1 \mathrm{~m}$ of core from $45 \mathrm{~m}$ of penetration in this hole, which makes reconstruction of the lithostratigraphy impossible, but the recovered core includes a wide diversity of lithologies that are typically associated with VHMS mineralization. In addition to the sphalerite-rich black ore, it includes a boulder-sized, coarsely crystalline piece of anhydrite veined by sphalerite-pyrite, as well as pyrite veined and altered volcanic rock. Detailed studies of these lithologies, in the context of all that is known about the active hydrothermal system at Iheya North Knoll, will provide direct evidence of how VHMS mineral deposits in general, and the $\mathrm{Ku}-$ roko ores in particular, are formed.

\section{Operations}

To achieve the scientific objectives of Expedition 331, drilling was planned at three main sites (proposed Sites INH-1D, INH-4D, and INH5-D, which were drilled as Sites C0016, C0013, and C0014, respectively). No less than nine additional sites were approved and considered as potential contingency sites. Of these, Proposed Sites INH-1C, INH-6B, and INH-11A were drilled as Sites C0016, C0017, and C0015, respectively.

The drilling plan was designed to penetrate the hydrothermal flow path, including the main discharge at NBC (Site C0016), a high heat flow area (Site C0013), and a low heat flow area (Site C0014). Drilling was prioritized according to potential scientific return, as well as operational feasibility. Main holes at Sites C0013 and C0014 were to be drilled through guide bases, cased with perforated casing, and supplied with corrosion caps. We carried a third guide base for a possible contingency, which was used in Hole C0016B. A complete list of sites and holes can be found in the general coring summary in Table T2. Unusual aspects of Expedition 331 include the high heat flow encountered especially at Sites C0013C0016. It also includes very short distances between sites, allowing the ship to reach even the most remote Site C0017 within hours of operating at the other sites. High levels of $\mathrm{H}_{2} \mathrm{~S}$ gas from the cores required most of the core recovery operation to be undertaken wearing breathing apparatus at the rig floor and core cutting areas. Finally, coring systems with two different diameters were used: IODP standard systems as carried by the Chikyu (HPCS, EPCS, and ESCS) with core diameters of 2.44 inches and a commercial system taking 4 inch diameter cores.

Initial drilling at Site C0013 quickly lead to the realization that the heat flow indeed was high there, causing the plastic liners to melt, which added issues for core extraction as well as concerns about contamination. Site C0013 was approved to a total depth of $100 \mathrm{~m}$, but the main Hole C0013E achieved a total depth of only 54.5 mbsf. The Chikyu eventually returned there to core with aluminum core liner and thereby retrieve cores not disturbed by thermal alteration of the liner material. Drilling at Site C0014 encountered the same issue, only slightly deeper.

Site C0014 is another discharge-recharge zone similar to Site C0013. The target depth was 200 mbsf, but drilling was terminated at 136.7 mbsf. The main objectives were reached by then, and the borehole assembly seals were starting to show damage from the heat, which was estimated to be up to $300^{\circ} \mathrm{C}$, based on the composition of precipitates in the recovered 
rocks. Hole C0014G was used for the casing operation there.

The heat issue led to drilling at the first contingency Site C0015 to use up about half a day until it was time for crew change and the opportunity to load aluminum core liners for the IODP standard coring systems. This site is a potential methane and fluid source west of the vent axis. (All other sites are located east of the axis.)

Site C0016 targeted the active hydrothermal vent system and was drilled using the commercial BHI 4 inch coring system. Hole C0016A targeted the crest of the NBC mound but recovered no core because the core barrel severed, leaving the drill bit and fullclosure core catcher of the commercial drilling assembly in the hole. The ship left the third guide base at the location for Hole C0016B before relocating to Site C0017. Hole C0016B was drilled as the last hole of the expedition, using the third guide base at the base of NBC mound. A depth of 45 mbsf was reached, but only $2 \mathrm{~m}$ of core was recovered. The guide base was capped with a $3 \mathrm{~m}$ section of casing added to function as an entry guide for downhole tools.

Site C0017 is a site of suspected cool seawater recharge to the hydrothermal system. Holes C0017A and C0017B were abandoned because the bit pulled out while retrieving the core barrel. Hole C0017C was abandoned when the core barrel came back without shoe or core catcher. The total depth of 150.7 mbsf was reached at Hole C0017D after a successful unguided reentry. This site provided a good temperature record using a combination of APCT3 and thermoseal strips, in addition to good core recovery. A happy surprise was very good recovery with the ESCS assembly of firm, sticky mud. When operations at Site C0017 were completed, the Chikyu returned to the guide base NBC mound to drill Hole C0016B.

\section{References}

Deming, J.W., and Baross, J.A., 1993. Deep-sea smokers: windows to a subsurface biosphere? Geochim. Cosmochim. Acta, 57(14):3219-3230. doi:10.1016/ 0016-7037(93)90535-5

D’Hondt, S., Jørgensen, B.B., Miller, D.J., Batzke, A., Blake, R., Cragg, B.A., Cypionka, H., Dickens, G.R., Ferdelman, T., Hinrichs, K.-U., Holm, N.G., Mitterer, R., Spivack, A., Wang, G., Bekins, B., Engelen, B., Ford, K., Gettemy, G., Rutherford, S.D., Sass, H., Skilbeck, C.G., Aiello, I.W., Guèrin, G., House, C.H., Inagaki, F., Meister, P., Naehr, T., Niitsuma, S., Parkes, R.J., Schippers, A., Smith, D.C., Teske, A., Wiegel, J., Naranjo Padillo, C., and Solis Acosta, J.L., 2004. Distributions of microbial activities in deep subseafloor sediments. Science, 306(5705):22162221. doi:10.1126/science.1101155

Emerson, D., Rentz, J.A., Lilburn, T.G., Davis, R.E., Aldrich, H., Chan, C., and Moyer, C.L., 2007. A novel lineage of Proteobacteria involved in formation of marine Fe-oxidizing microbial mat communities. PLoS ONE, 2(8):e667. doi:10.1371/journal.pone.0000667

Expedition 331 Scientists, 2011a. Site C0013. In Takai, K., Mottl, M.J., Nielsen, S.H., and the Expedition 331 Scientists, Proc. IODP, 331: Tokyo (Integrated Ocean Drilling Program Management International, Inc.).

doi:10.2204/iodp.proc.331.103.2011

Expedition 331 Scientists, 2011b. Site C0014. In Takai, K., Mottl, M.J., Nielsen, S.H., and the Expedition 331 Scientists, Proc. IODP, 331: Tokyo (Integrated Ocean Drilling Program Management International, Inc.). doi:10.2204/iodp.proc.331.104.2011

Expedition 331 Scientists, 2011c. Site C0015. In Takai, K., Mottl, M.J., Nielsen, S.H., and the Expedition 331 Scientists, Proc. IODP, 331: Tokyo (Integrated Ocean Drilling Program Management International, Inc.). doi:10.2204/iodp.proc.331.105.2011

Expedition 331 Scientists, 2011d. Site C0016. In Takai, K., Mottl, M.J., Nielsen, S.H., and the Expedition 331 Scientists, Proc. IODP, 331: Tokyo (Integrated Ocean Drilling Program Management International, Inc.). doi:10.2204/iodp.proc.331.106.2011

Expedition 331 Scientists, 2011e. Site C0017. In Takai, K., Mottl, M.J., Nielsen, S.H., and the Expedition 331 Scientists, Proc. IODP, 331: Tokyo (Integrated Ocean Drilling Program Management International, Inc.). doi:10.2204/iodp.proc.331.107.2011

Fontaine, F.J., and Wilcock, W.S.D, 2006. Dynamics and storage of brine in mid-ocean ridge hydrothermal systems. J. Geophys. Res., [Solid Earth], 111(B6):B06102. doi:10.1029/2005JB003866

Gamo, T., Sakai, H., Kim, E.-S., Shitashima, K., and Ishibashi, J., 1991. High alkalinity due to sulfate reduction in the CLAM hydrothermal field, Okinawa Trough. Earth Planet. Sci. Lett., 107(2):328-338. doi:10.1016/ 0012-821X(91)90080-2

Gamo, T., Ishibashi, J., Tsunogai, U., Okamura, K., and Chiba, H., 2006. Unique geochemistry of submarine hydrothermal fluids from arc-back-arc settings of the Western Pacific. In Christie, D.M., Fisher, C.R., Lee, S.M., and Givens, S. (Eds.), Back-arc Spreading Systems: Geological, Biological, Chemical, and Physical interactions. Geophys. Monogr., 166:147-161.

Glasby, G.P., and Notsu, K., 2003. Submarine hydrothermal mineralization in the Okinawa Trough, SW of Japan: an overview. Ore Geol. Rev., 23(3-4):299-339. doi:10.1016/j.oregeorev.2003.07.001

Halbach, P., Nakamura, K., Wahsner, M., Lange, J., Sakai, H., Käselitz, L., Hansen, R.-D., Yamano, M., Post, J., Prause, B., Seifert, R., Michaelis, W., Teichmann, F., Kinoshita, M., Märten, A., Ishibashi, J., Czerwinski, S., and Blum, N., 1989. Probable modern analogue of Kuroko-type massive sulphide deposits in the Okinawa Trough back-arc basin. Nature (London, U. K.), 338(6215):496-499. doi:10.1038/338496a0 
Halbach, P., Pracejus, B., and Maerten, A., 1993. Geology and mineralogy of massive sulfide ores from the central Okinawa Trough, Japan. Econ. Geol., 88(8):2210-2225. doi:10.2113/gsecongeo.88.8.2210

Huber, J.A., and Holden, J.F., 2008. Modeling the impact of diffuse vent microorganisms along mid-ocean ridges and flanks. In Lowell, R.P., Seewald, J.S., Metaxas, A., and Perfit, M.R. (Eds.), Magma to Microbe: Modeling Hydrothermal Processes at Oceanic Spreading Centers. Geophys. Monogr., 178:215-231.

Humphris, S.E., Herzig, P.M., Miller, D.J., Alt, J.C., Becker, K., Brown, D., Brügmann, G., Chiba, H., Fouquet, Y., Gemmell, J.B., Guerin, G., Hannington, M.D., Holm, N.G., Honnorez, J.J., Itturino, G.J., Knott, R., Ludwig, R., Nakamura, K., Petersen, S., Reysenbach, A.-L., Rona, P.A., Smith, S., Sturz, A.A., Tivey, M.K., and Zhao, X., 1995. The internal structure of an active sea-floor massive sulphide deposit. Nature (London, U. K.), 377(6551):713-716. doi:10.1038/377713a0

Inagaki, F., Kuypers, M.M.M., Tsunogai, U., Ishibashi, J., Nakamura, K., Treude, T., Ohkubo, S., Nakaseama, M., Gena, K., Chiba, H., Hirayama, H., Nunoura, T., Takai, K., Jørgensen, B.B., Horikoshi, K., and Boetius, A., 2006. Microbial community in a sediment-hosted $\mathrm{CO}_{2}$ lake of the southern Okinawa Trough hydrothermal system. Proc. Natl. Acad. Sci. U. S. A., 103(38):14164-14169. doi:10.1073/pnas.0606083103

Kawagucci, S., Chiba, H., Ishibashi, J., Yamanaka, T., Toki, T., Muramatsu, Y., Ueno, Y., Makabe, A., Inoue, K., Yoshida, N., Nakagawa, S., Nunoura, T., Takai, K., Takahata, N., Sano, Y., Narita, T., Teranishi, G., Obata, H., and Gamo, T., 2011. Hydrothermal fluid geochemistry at the Iheya north field in the mid-Okinawa Trough: implication for origin of methane in subseafloor fluid circulation systems. Geochem. J., 45(2):109-124. http:// www.terrapub.co.jp/journals/GJ/abstract/4502/ 45020109.html

Konno, U., Tsunogai, U., Nakagawa, F., Nakaseama, M., Ishibashi, J., Nunoura, T., and Nakamura, K., 2006. Liquid $\mathrm{CO}_{2}$ venting on the seafloor: Yonaguni Knoll IV hydrothermal system, Okinawa Trough. Geophys. Res. Lett., 33(16):L16607. doi:10.1029/2006GL026115

Kumagai, H., Tsukioka, S., Yamamoto, H., Tsuji, T., Shitashima, K., Asada, M., Yamamoto, F., and Kinoshita, M., in press. Hydrothermal plumes imaged by high-resolution side-scan sonar on a cruising AUV, Urashima. Geochem., Geophys. Geosys.

Lee, C.-S., Shor, G.G., Jr., Bibee, L.D., Lu, R.S., and Hilde, T.W.C., 1980. Okinawa Trough: origin of a back-arc basin. Mar. Geol., 35(1-3):219-241. doi:10.1016/ 0025-3227(80)90032-8

Letouzey, J., and Kimura, M., 1986. The Okinawa Trough: genesis of a backarc basin developing along a continental margin. Tectonophysics, 125(1-3):209-230. doi:10.1016/0040-1951(86)90015-6

Masaki, Y., Kinoshita, M., Inagaki, F., Nakagawa, S., and Takai, K., 2011. Possible kilometer-scale hydrothermal circulation within the Iheya-North field, mid-Okinawa Trough, as inferred from heat flow data. JAMSTEC Rep.
Res. Dev., 12:1-12. http://docsrv.godac.jp/ MSV2_DATA/23/JAM_RandD12_01.pdf

Nakagawa, S., Takai, K., Inagaki, F., Chiba, H., Ishibashi, J., Kataoka, S., Hirayama, H., Nunoura, T., Horikoshi, K., and Sako, Y., 2005. Variability in microbial community and venting chemistry in a sediment-hosted backarc hydrothermal system: impacts of subseafloor phase-separation. FEMS Microbiol. Ecol., 54(1):141-155. doi:10.1016/j.femsec.2005.03.007

Narita, H., Harada, K., and Tsunogai, S., 1990. Lateral transport of sediment particles in the Okinawa Trough determined by natural radionuclides. Geochem. J., 24:207-216.

Nunoura, T., Oida, H., Nakaseama, M., Kosaka, A., Ohkubo, S.B., Kikuchi, T., Kazama, H., Hosoi-Tanabe, S., Nakamura, K., Kinoshita, M., Hirayama, H., Inagaki, F., Tsunogai, U., Ishibashi, J., and Takai, K., 2010. Archaeal diversity and distribution along thermal and geochemical gradients in hydrothermal sediments at the Yonaguni Knoll IV hydrothermal field in the southern Okinawa Trough. Appl. Environ. Microbiol., 76(4):11981211. doi:10.1128/AEM.00924-09

Nunoura, T., and Takai, K. 2009. Comparison of microbial communities associated with phase-separation-induced hydrothermal fluids at the Yonaguni Knoll IV hydrothermal field, the Southern Okinawa Trough. FEMS Microbiol. Ecol., 67:351-370.

Oiwane, H., Kumagai, Y., Nakamura, Y., and Tokuyama, H., 2008. Characteristics of sediment in Iheya North Knoll and "the acoustic blanking layer." JPGU Meeting, Abstract J164-P013. http://wwwsoc.nii.ac.jp/jepsjmo/ cd-rom/2008cd-rom/program/pdf/J164/J164P013_e.pdf

Parkes, R.J., Cragg, B.A., Bale, S.J., Getliff, J.M., Goodman, K., Rochelle, P.A., Fry, J.C., Weightman, A.J., and Harvey, S.M., 1994. Deep bacterial biosphere in Pacific Ocean sediments. Nature (London, U. K.), 371(6496):410-413. doi:10.1038/371410a0

Parkes, R.J., Cragg, B.A., and Wellsbury, P., 2000. Recent studies on bacterial populations and processes in subseafloor sediments: a review. Hydrogeol. J., 8(1):11-28. doi:10.1007/PL00010971

Rassa, A.C., McAllister, S.M., Safran, S.A., and Moyer, C.L., 2009. Zeta-Proteobacteria dominate the colonization and formation of microbial mats in low-temperature hydrothermal vents at Loihi Seamount, Hawaii. Geomicrobiol. J., 26(8):623-638.

Sakai, H., Gamo, T., Kim, E.-S., Shitashima, K., Yanagisawa, F., Tsutsumi, M., Ishibashi, J., Sano, Y., Wakita, H., Tanaka, T., Matsumoto, T., Naganuma, T., and Mitsuzawa, K., 1990a. Unique chemistry of the hydrothermal solution in the mid-Okinawa Trough backarc basin. Geophys. Res. Lett., 17(12):2133-2136. doi:10.1029/ GL017i012p02133

Sakai, H., Gamo, T., Kim, E.-S., Tsutsumi, M., Tanaka, T., Ishibashi, J., Wakita, H., Yamano, M., and Oomori, T., 1990b. Venting of carbon dioxide-rich fluid and hydrate formation in mid-Okinawa Trough backarc basin. Science, 248(4959):1093-1096. doi:10.1126/science.248.4959.1093 
Schrum, H.N., Spivack, A.J., Kastner, M., and D'Hondt, S., 2009. Sulfate-reducing ammonium oxidation: a thermodynamically feasible metabolic pathway in subseafloor sediment. Geology, 37(10):939-942. doi:10.1130/ G30238A.1

Shipboard Scientific Party, 2002. Leg 193 summary. In Binns, R.A., Barriga, F.J.A.S., Miller, D.J., et al., Proc. ODP, Init. Repts., 193: College Station, TX (Ocean Drilling Program). doi:10.2973/odp.proc.ir.193.101.2002

Suzuki, R., Ishibashi, J., Nakaseama, M., Konno, U., Tsunogai, U., Gena, K., and Chiba, H., 2008. Diverse range of mineralization induced by phase separation of hydrothermal fluid: case study of the Yonaguni Knoll IV hydrothermal field in the Okinawa Trough back-arc basin. Res. Geol., 58(3):267-288. doi:10.1111/j.17513928.2008.00061.x

Takai, K., Gamo, T., Tsunogai, U., Nakayama, N., Hirayama, H., Nealson, K.H., and Horikoshi, K., 2004. Geochemical and microbiological evidence for a hydrogen-based, hyperthermophilic subsurface lithoautotrophic microbial ecosystem (HyperSLiME) beneath an active deep-sea hydrothermal field. Extremophiles, 8(4):269-282. doi:10.1007/s00792-004-0386-3

Takai, K., and Horikoshi, K., 1999. Genetic diversity of archaea in deep-sea hydrothermal vent environments. Genetics, 152:1285-1297.

Takai, K., Inagaki, F., Nakagawa, S., Hirayama, H., Nunoura, T., Sako, Y., Nealson, K.H., and Horikoshi, K., 2003. Isolation and phylogenetic diversity of members of previously uncultivated $\varepsilon$-Proteobacteria in deep-sea hydrothermal fields. FEMS Microbiol. Lett., 218(1):167174. doi:10.1111/j.1574-6968.2003.tb11514.x

Takai, K., Nakagawa, S., Reysenbach, A.L., and Hoek, J., 2006. Microbial ecology of mid-ocean ridges and backarc basins. In Christie, D.M., Fisher, C.R., Lee, S.M., and Givens, S. (Eds.), Back-Arc Spreading Systems: Geological, Biological, Chemical and Physical Interactions. Geophys. Monogr., 166:185-213.
Takai, K., and Nakamura, K., 2010. Compositional, physiological and metabolic variability in microbial communities associated with geochemically diverse, deep-sea hydrothermal vent fluids. In Barton, L., Mendl, M., and Loy, A. (Eds.), Geomicrobiology: Molecular and Environmental Perspective: New York (Springer), 251-283. doi:10.1007/978-90-481-9204-5_12

Takai, K., Nunoura, T., Ishibashi, J., Lupton, J., Suzuki, R., Hamasaki, H., Ueno, Y., Kawagucci, S., Gamo, T., Suzuki, Y., Hirayama, H., and Horikoshi, K., 2008. Variability in the microbial communities and hydrothermal fluid chemistry at the newly discovered Mariner hydrothermal field, southern Lau Basin. J. Geophys. Res., [Biogeosci.], 113(G2):G02031. doi:10.1029/2007JG000636

Takai, K., Nunoura, T., Horikoshi, K., Shibuya, T., Nakamura, K., Suzuki, Y., Stott, M., Massoth, G.J., Christenson, B.W., deRonde, C.E.J., Butterfield, D.A., Ishibashi, J., Lupton, J.E., and Evans, L.J., 2009. Variability in microbial communities in black smoker chimneys at the NW caldera vent field, Brothers Volcano, Kermadec arc. Geomicrobiol. J., 26(8):552-569.

Ueno, H., Hamasaki, H., Murakawa, Y., Kitazono, S., and Takeda, T., 2003. Ore and gangue minerals of sulfide chimneys from the North Knoll, Iheya Ridge, Okinawa Trough, Japan. JAMSTEC J. Deep Sea Res., 22:49-62. http://docsrv.godac.jp/MSV2_DATA/23/22_06.pdf

Urabe, T., and Marumo, K., 1991. A new model for Kurokotype deposits of Japan. Episodes, 14(3):246-251.

You, C.-F., Butterfield, D.A., Spivack, A.J., Gieskes, J.M., Gamo, T., and Campbell, A.J., 1994. Boron and halide systematics in submarine hydrothermal systems: effects of phase separation and sedimentary contributions. Earth. Planet. Sci. Lett., 123(1-3):227-238. doi:10.1016/ 0012-821X(94)90270-4

Publication: 4 October 2011 MS 331-101 
Figure F1. Area map of Iheya North Knoll showing Sites C0013-C0017 drilled during Expedition 331. Inserts show the Iheya North Knoll in relation to Okinawa and Okinawa in relation to major tectonic components. Yellow lines on the map show a grid of MCS and SCS survey lines. EUR = Eurasian plate, PHS = Philippine Sea plate.

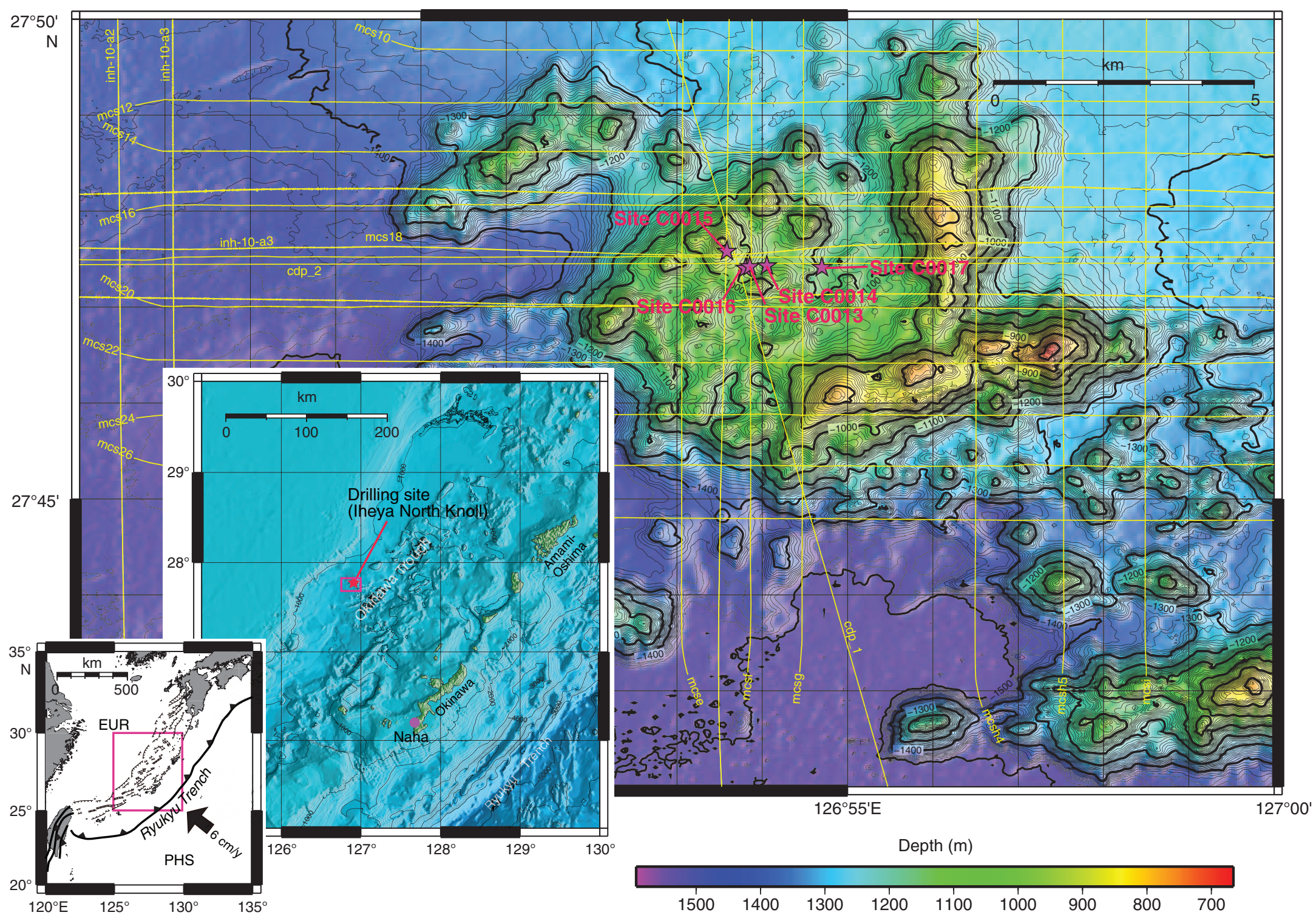




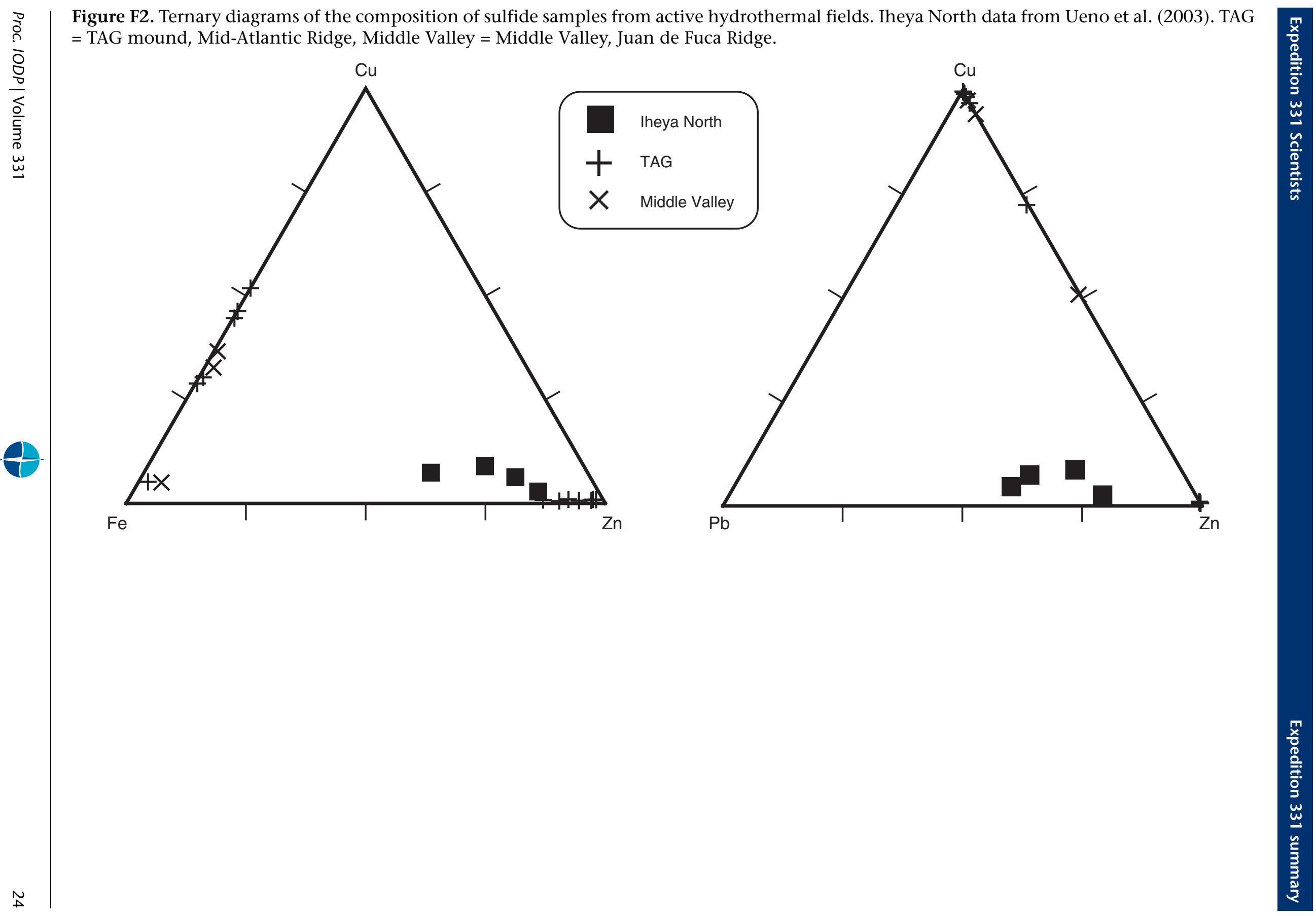


Figure F3. Detailed bathymetry of the Iheya North hydrothermal field and the central valley at Iheya North Knoll, with the location of Sites C0013-C0017 drilled during Expedition 331. HRV = High Radioactive Vent mound, CBC = Central Big Chimney, SBC = South Big Chimney mound, NEC = North Edge Chimney mound, E18 = event Marker 18 mound, NBC = North Big Chimney mound, ESBC = "Ese" South Big Chimney mound.
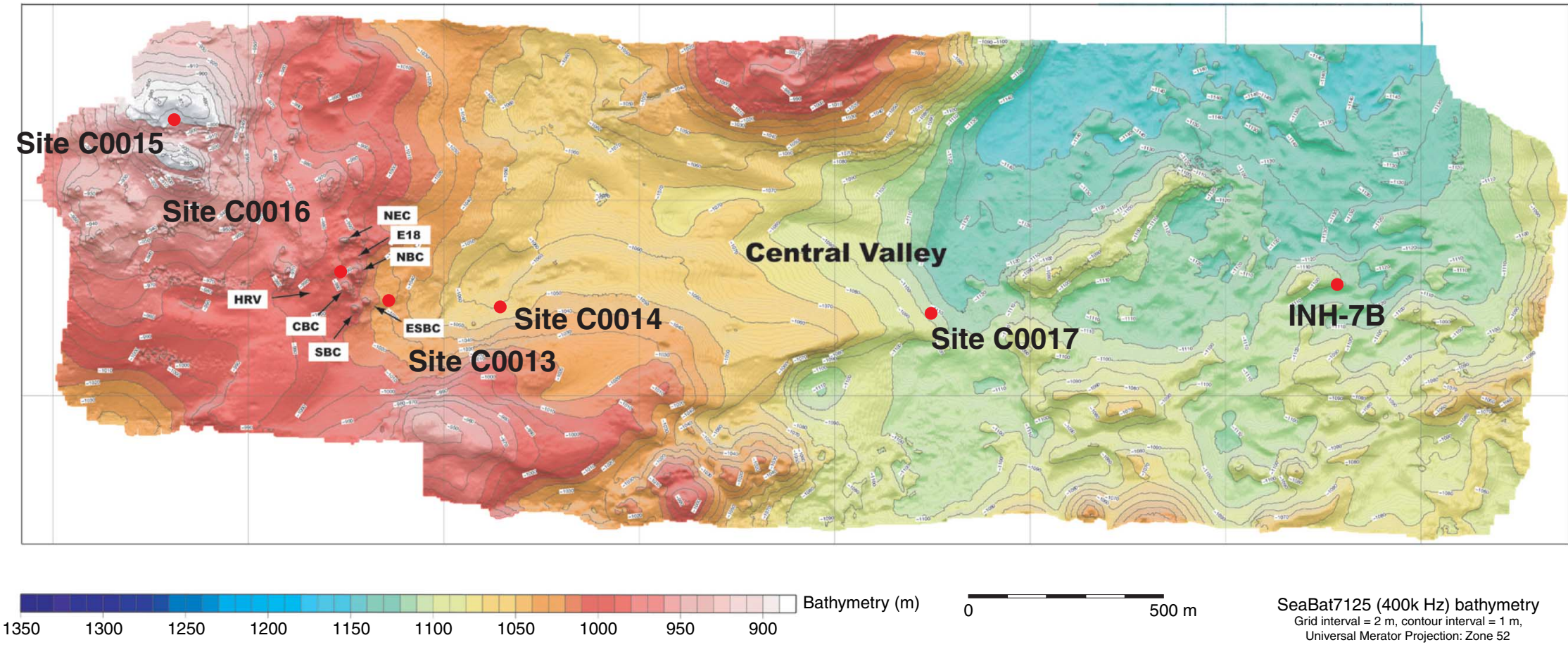
Figure F4. Block diagram constructed from MCS profiles around Iheya North Knoll. Black bars indicate sites drilled during Expedition 331 and depths assuming that $1 \mathrm{~s}$ two-way traveltime $=750 \mathrm{~m}$. Green bars indicate proposed sites and drilling depths.

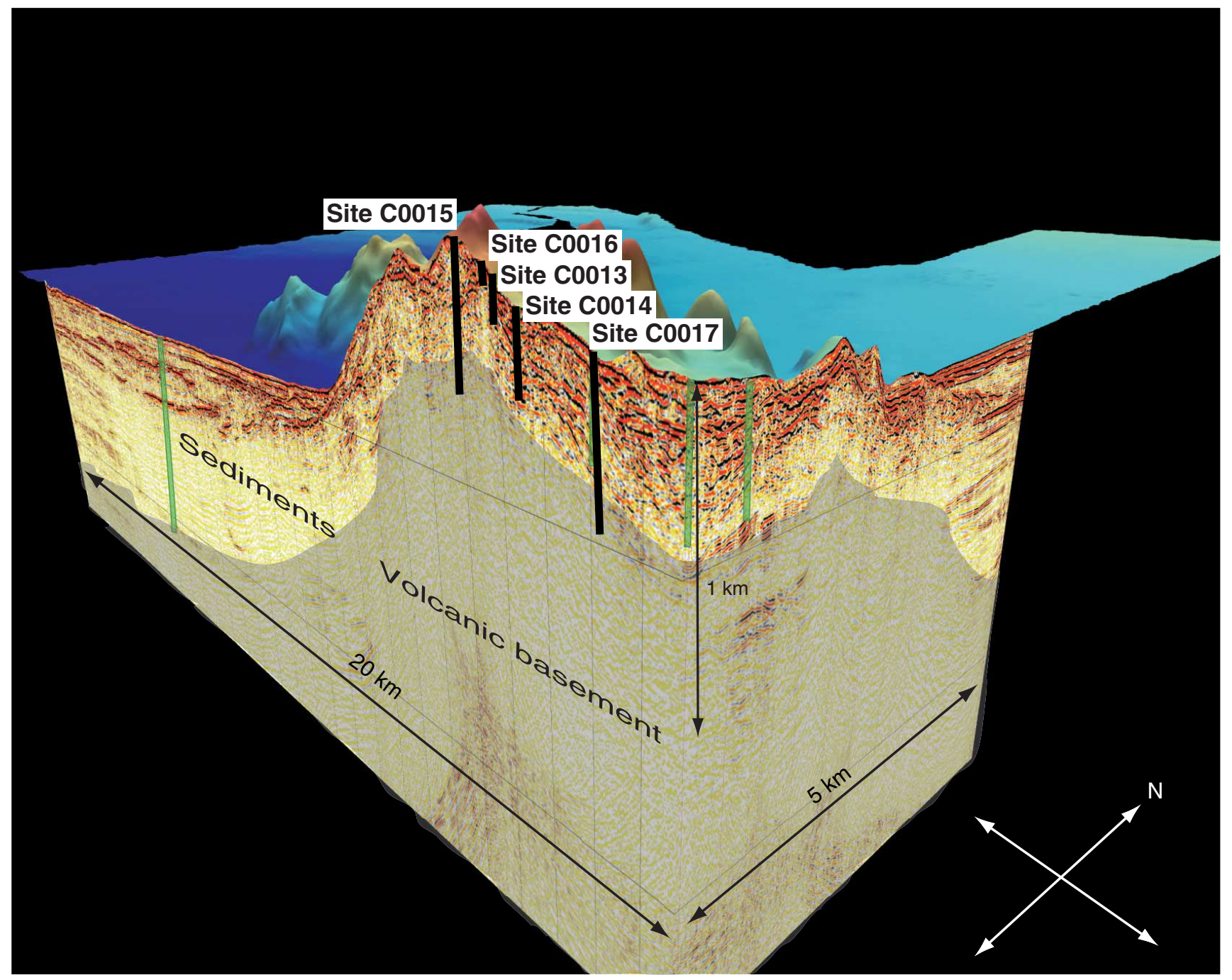


Figure F5. Cross section, looking north, of subseafloor structure of the hydrothermal field and the central valley of Iheya North Knoll based on the profile of multichannel seismic Line MCS18. Expedition 331 drilling sites and their actual drilled depths are shown as blue bars along with possible lithological interpretation assuming that $1 \mathrm{~s}$ two-way traveltime $=750 \mathrm{~m}$. Units $(\mathrm{A}, \mathrm{B}$, and $\mathrm{C})$ are those identified from the seismic reflection profile prior to drilling. Curved colored lines represent an attempt to correlate significant reflectors. CDP $=$ common depth point.

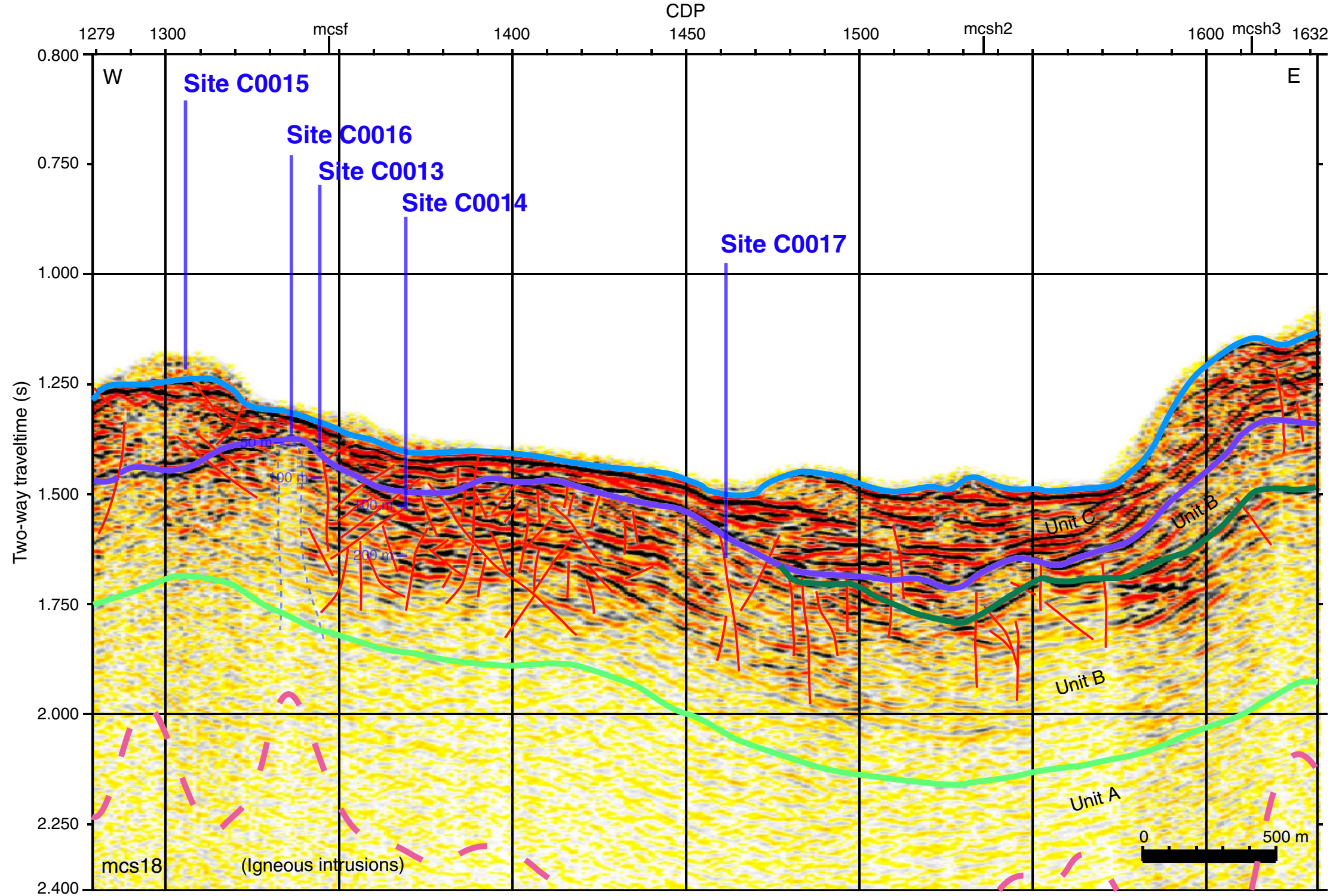


Figure F6. Cross section, looking north, of subseafloor structure of the hydrothermal field and the central valley of Iheya North based on the profile of multichannel seismic Line MCS18. Expedition 331 drilling sites and actual drilled depths (assuming that $1 \mathrm{~s}$ two-way traveltime $=750$ $\mathrm{m}$ ) are shown as blue bars, along with a possible hydrogeologic interpretation. Black and gray blank diamonds show the upper and lower reflections of potential volcaniclastic deposits beneath the central valley of Iheya North Knoll. These volcanic deposits are possible subseafloor hydrothermal migration paths. In contrast, black and gray blank circles show the upper and lower bounds of negatively polarized reflection sequences beneath the western hill structure near the vent sites. These negative polarity sequences are presently interpreted as very porous, fractured deposits that may host a hydrothermal reservoir and fluid migration paths.

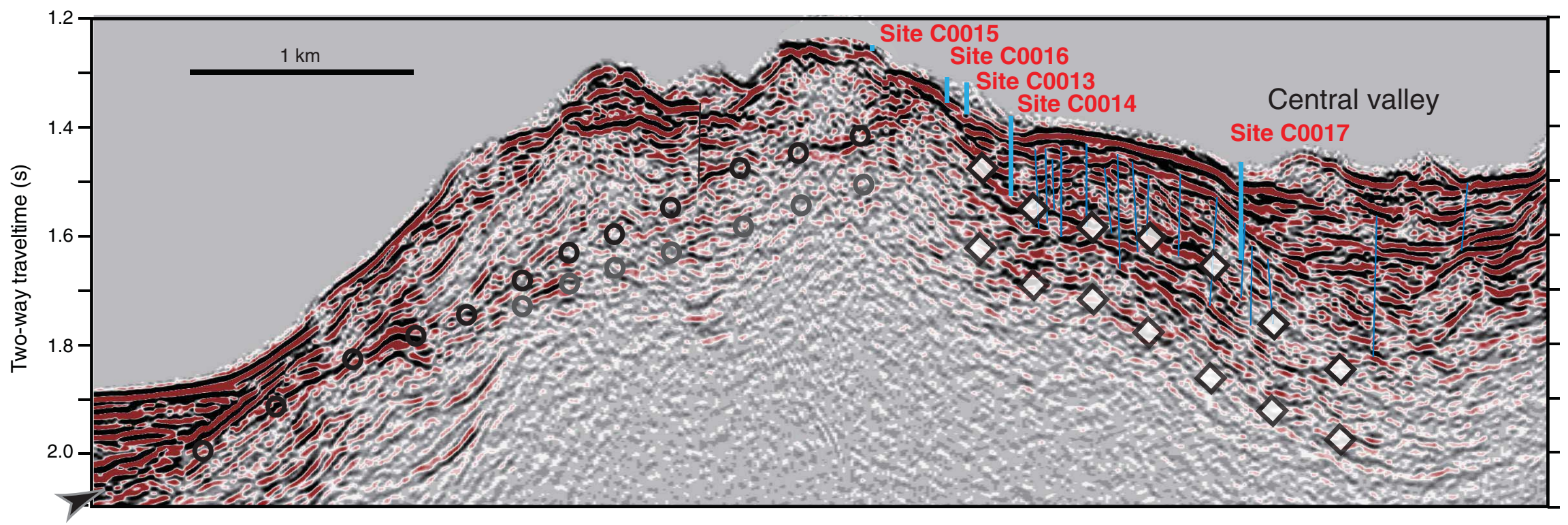


Figure F7. Photomosaic of the North Big Chimney (NBC) hydrothermal mound and photos of associated chemosynthetic animal communities at the Iheya North field.

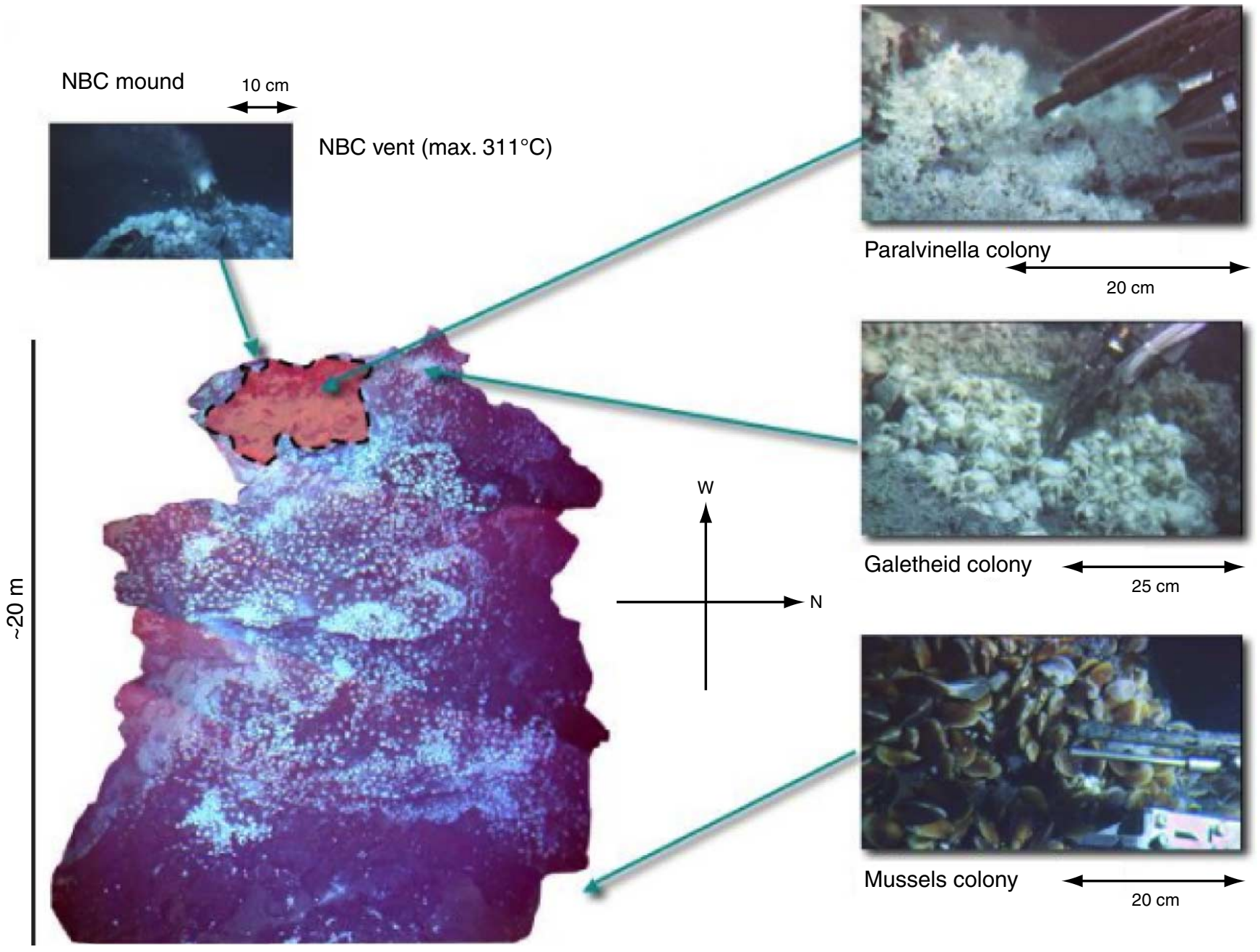


Figure F8. Schematic illustration of drilling and coring systems used, drilling and core recovery from Site C0013. $\mathrm{EPCS}=$ extended punch coring system, HPCS = hydraulic piston coring system, ESCS = extended shoe coring system, BHI = Baker-Hughes Inteq.

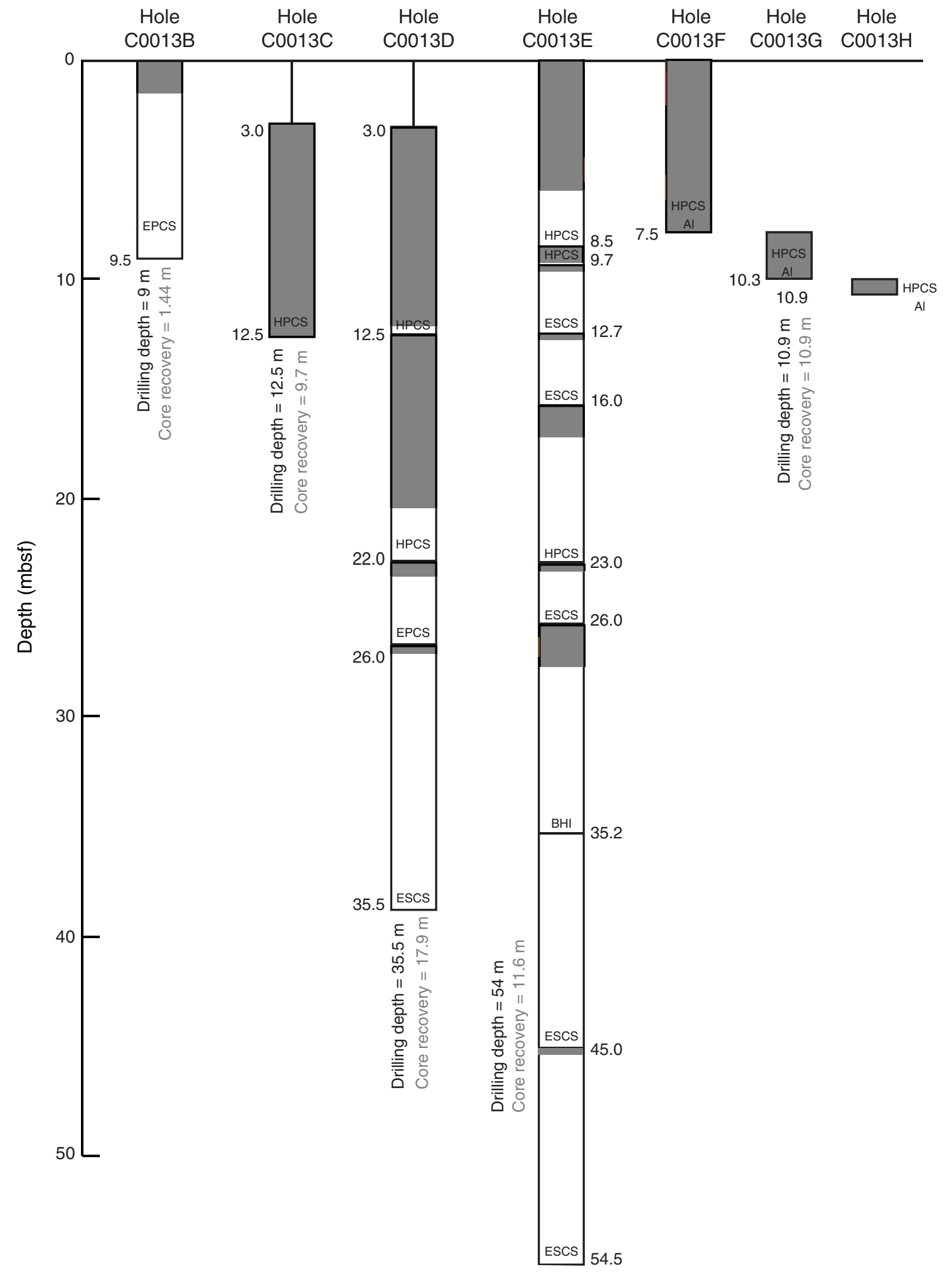


Figure F9. Schematic illustration of artificial hydrothermal vents created during Expedition 331. Outflow temperatures measured by the ROV Hyper Dolphin (Hole C0013E) and thermal stickers (Holes C0014G and C0016B). Section looking to the north. HPCS = hydraulic piston coring system, ESCS = extended shoe coring system, EPCS = extended punch coring system.

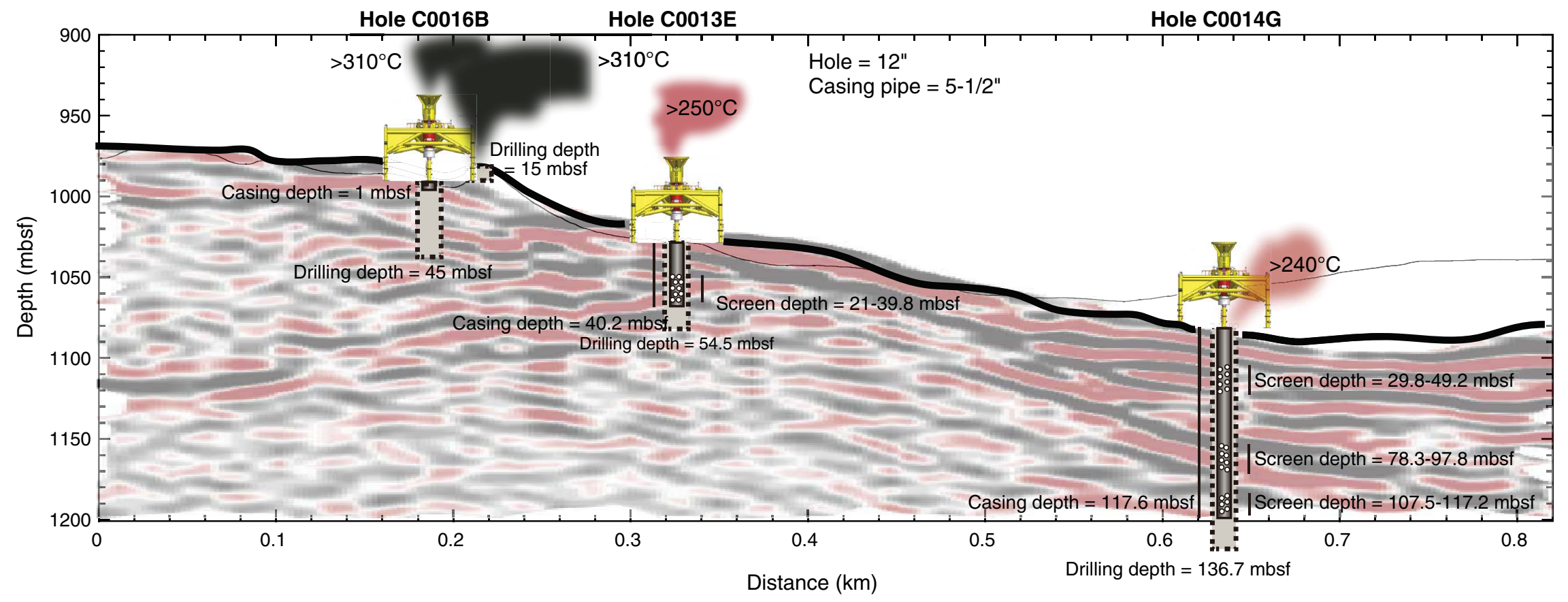


Figure F10. Schematic illustration of drilling and coring systems used, drilling, and core recovery from Site C0014.

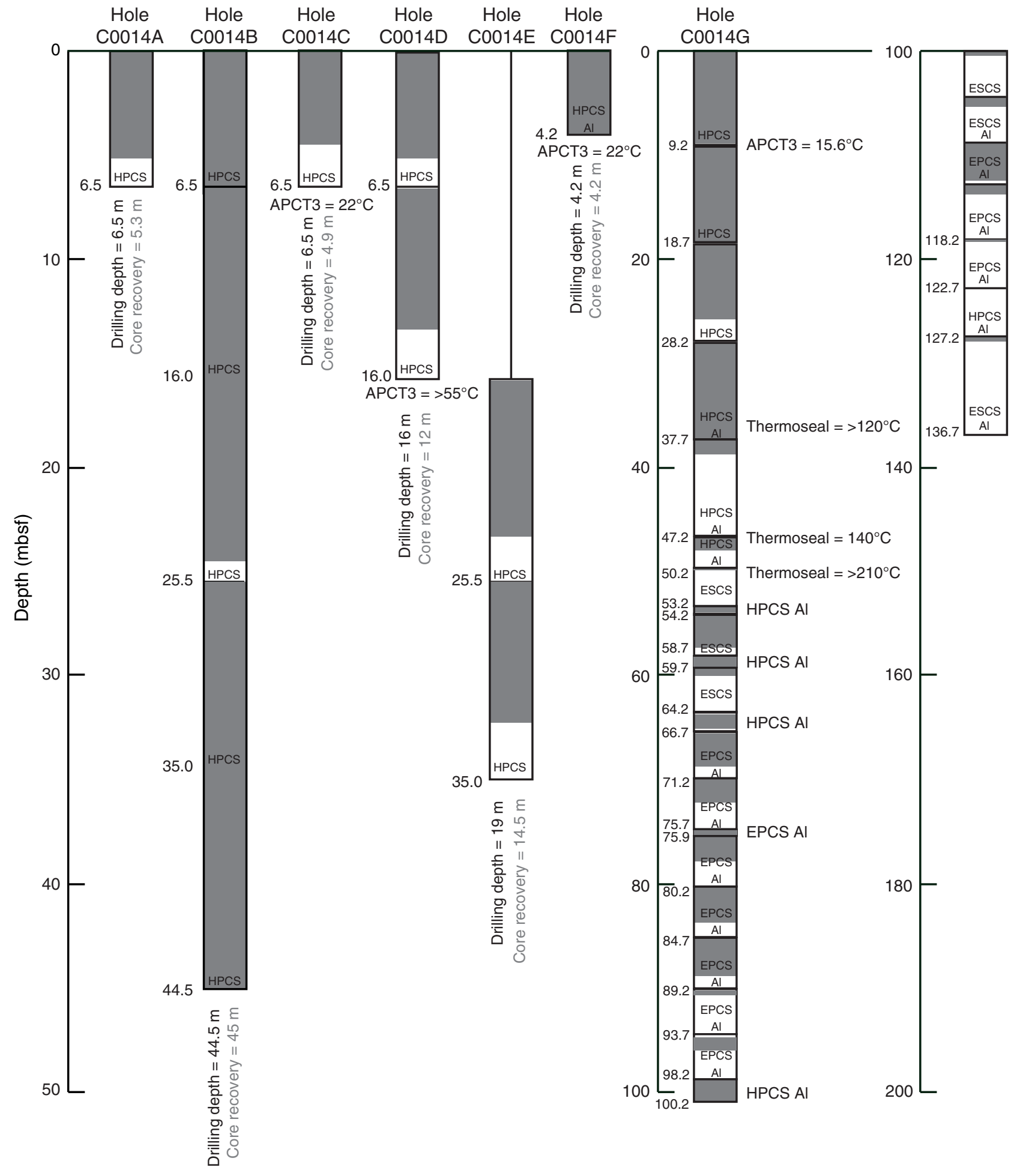


Figure F11. Depth profile of temperature in the subseafloor at Site C0014, as measured by the by APCT3 shoe and thermoseal chemically impregnated temperature-sensitive strips. Yellow = APCT3, black = thermoseal strip. Stars $=$ minimum values.

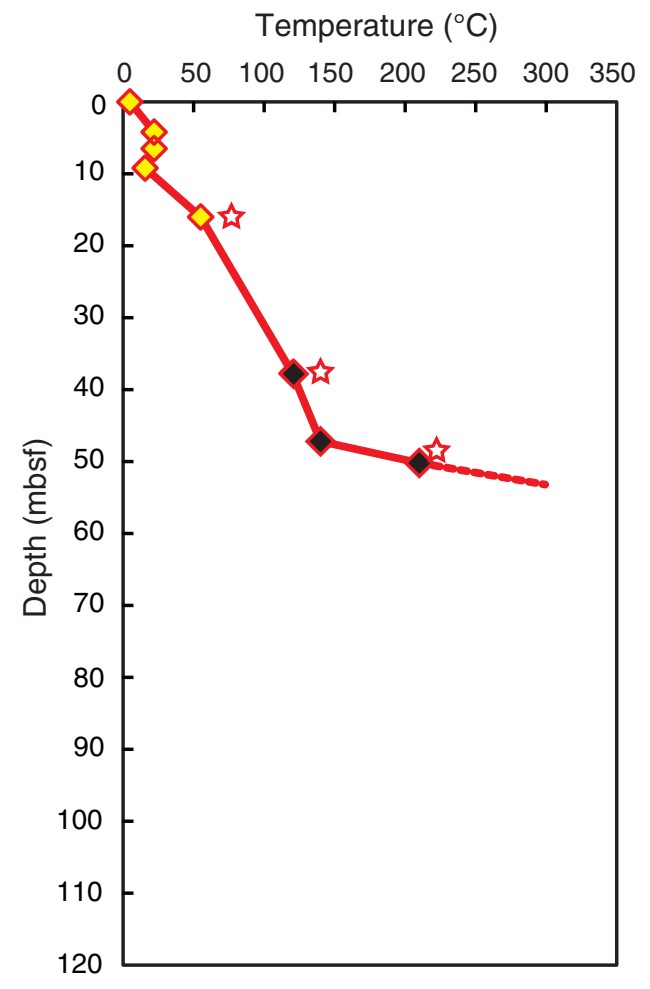


Figure F12. Schematic illustration of drilling and coring systems used, drilling and core recovery depths, and brief remarks on drilling operations and specific features of core recovered from Site C0015.

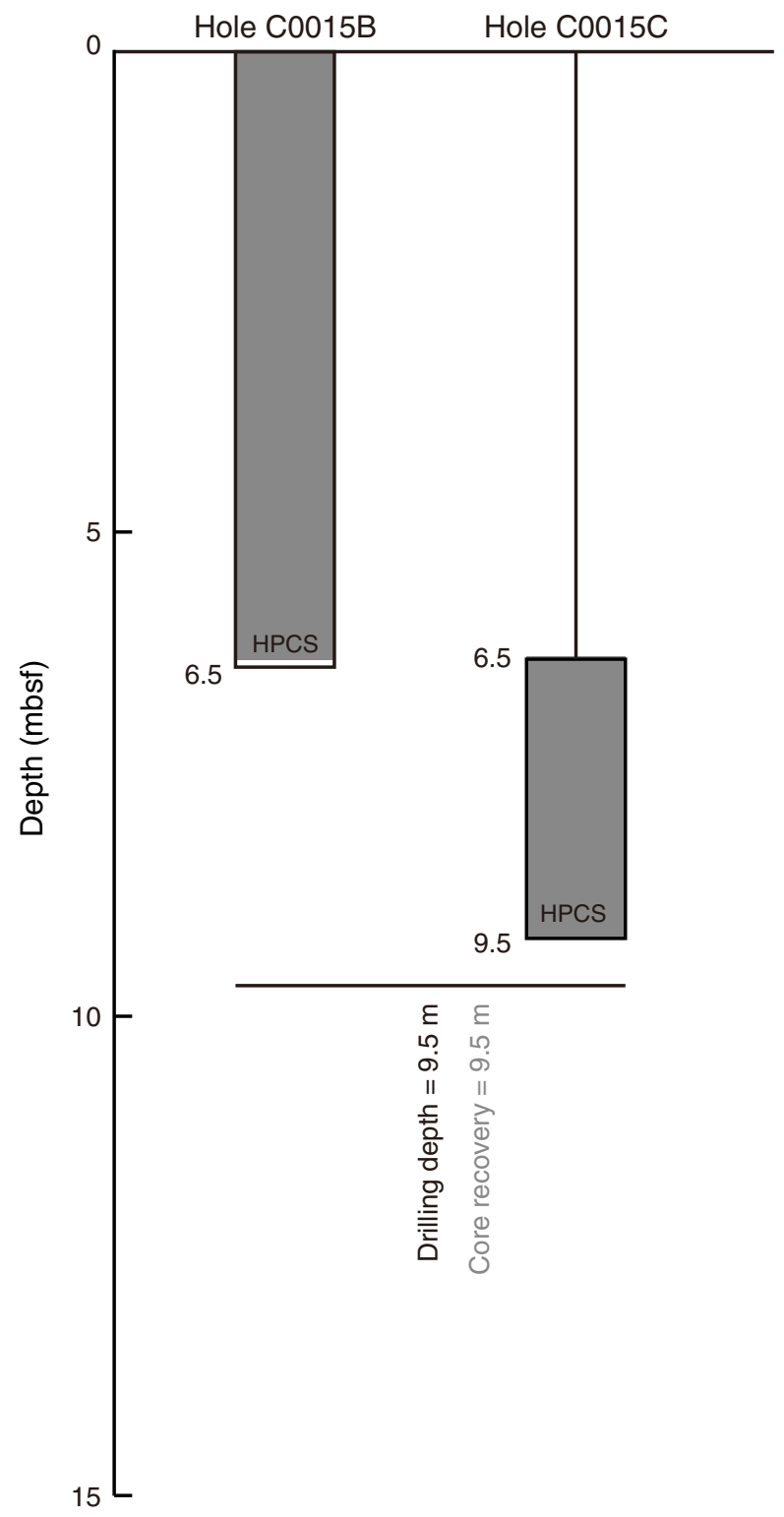


Figure F13. Schematic illustration of drilling and coring systems used, drilling and core recovery depths, and brief remarks on drilling operations and specific features of cores recovered from Site C0016. BHI = BakerHughes Inteq.

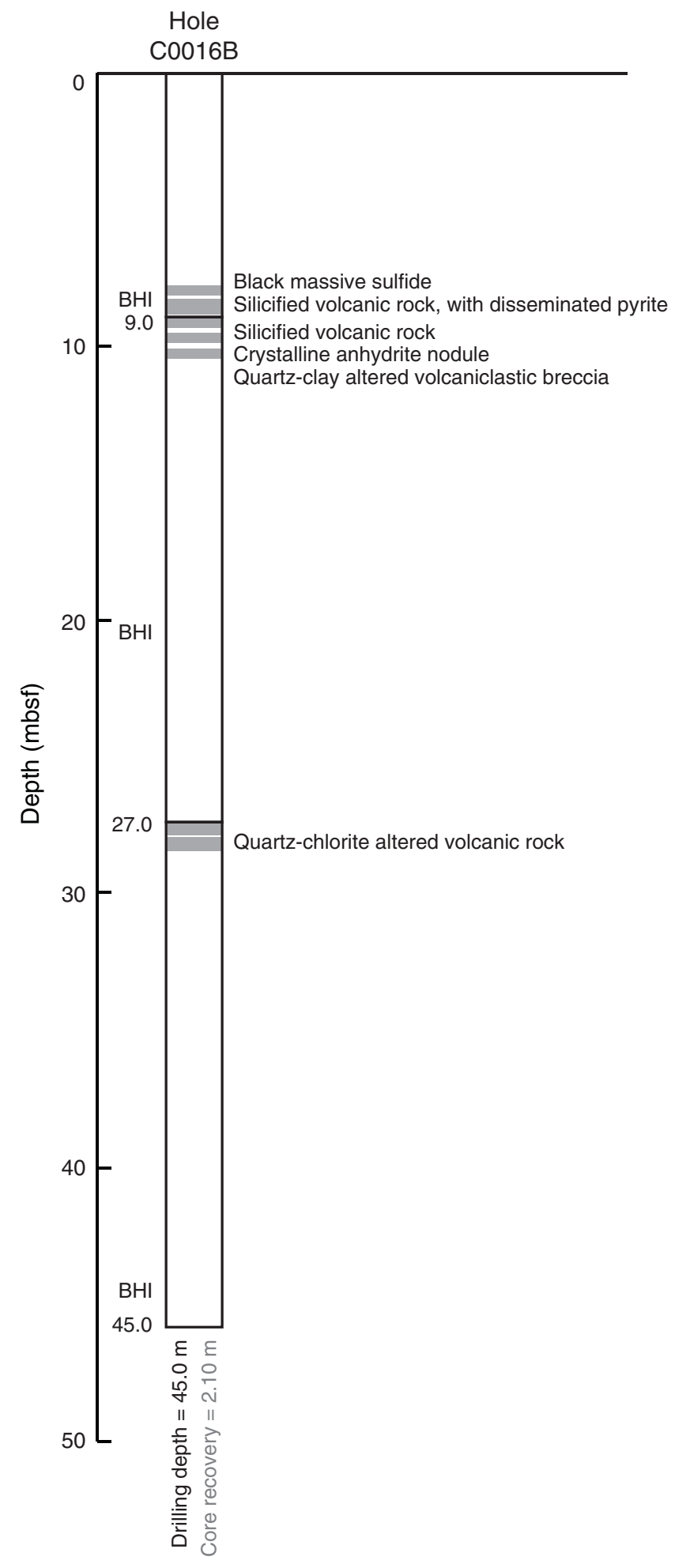


Figure F14. Schematic illustration of drilling and coring systems used, drilling and core recovery from Site C0017. EPCS = extended punch coring system, HPCS = hydraulic piston coring system, ESCS $=$ extended shoe coring system.

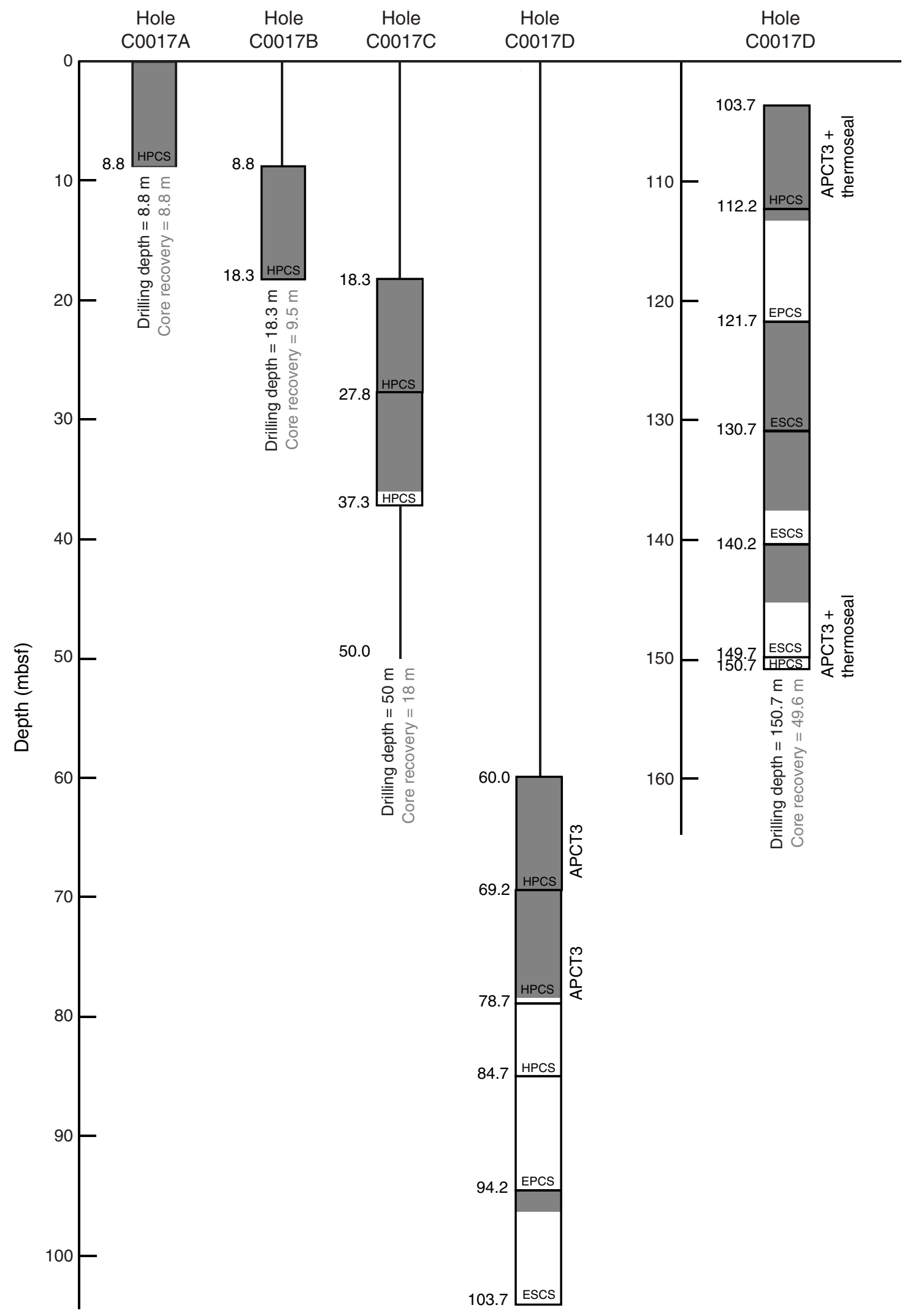


Figure F15. Plot of equilibrium temperature (red circles) and thermal conductivity, Site C0017. The point at 0 mbsf is the average bottom water temperature. Temperatures between 0 and 112 mbsf are from the APCT3 tool, and the temperature at $150.7 \mathrm{mbsf}$ is derived from the thermoseal on the core barrel.

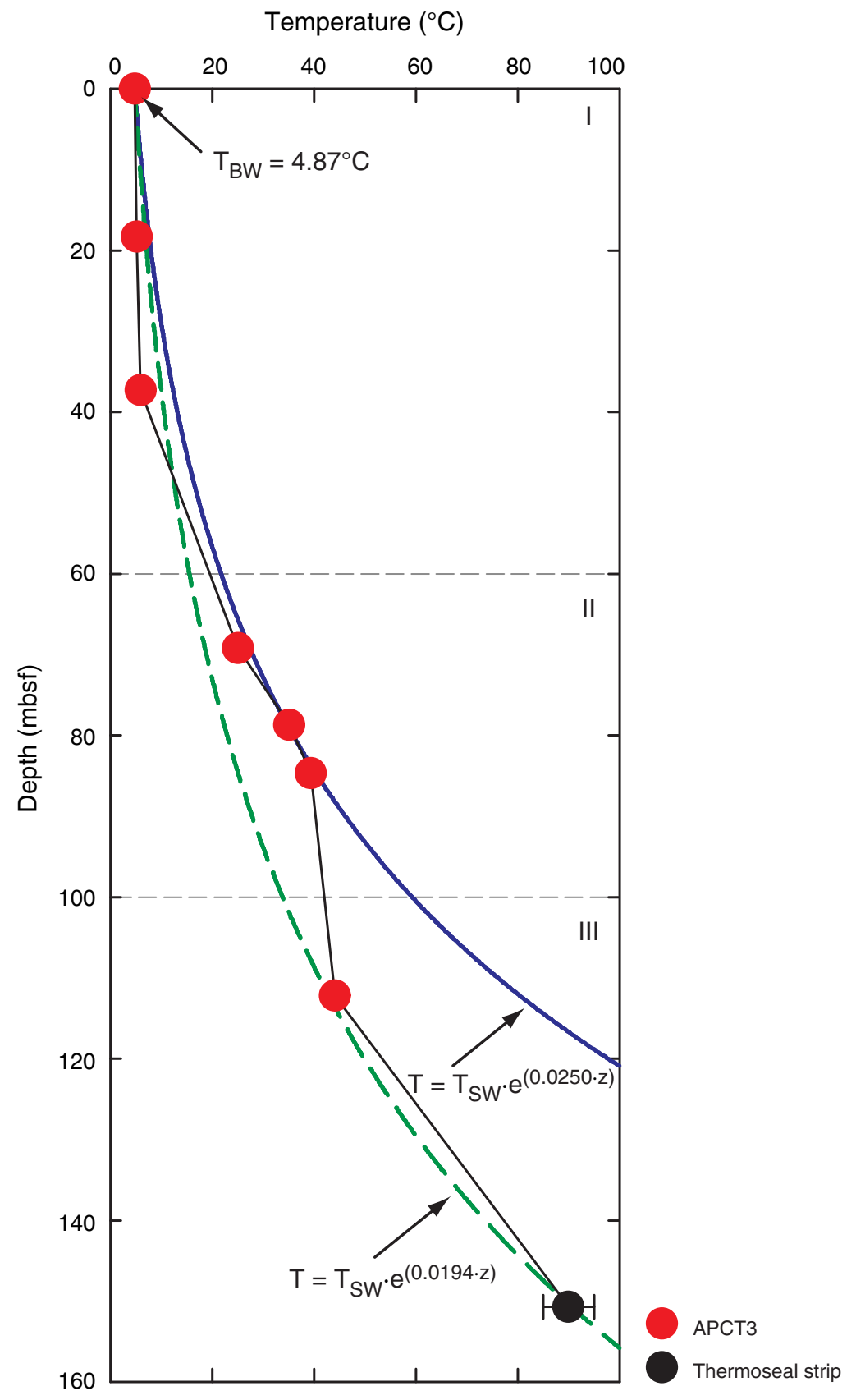


Figure F16. Schematic illustration of the possible spatial extent of subseafloor hydrothermal fluid flow and reservoirs (red) and recharged seawater advection (blue) based on preexisting seismic interpretation and drilling results from Expedition 331. Bars indicate the deeper holes drilled during Expedition 331 and their total penetration depths. The yellow dotted line denotes the shallowest depth of high temperatures of hydrothermal fluids we encountered during the expedition. Hole depths are fit to the seismic reflection profile assuming that $1 \mathrm{~s}$ two-way traveltime $=750 \mathrm{~m}$.

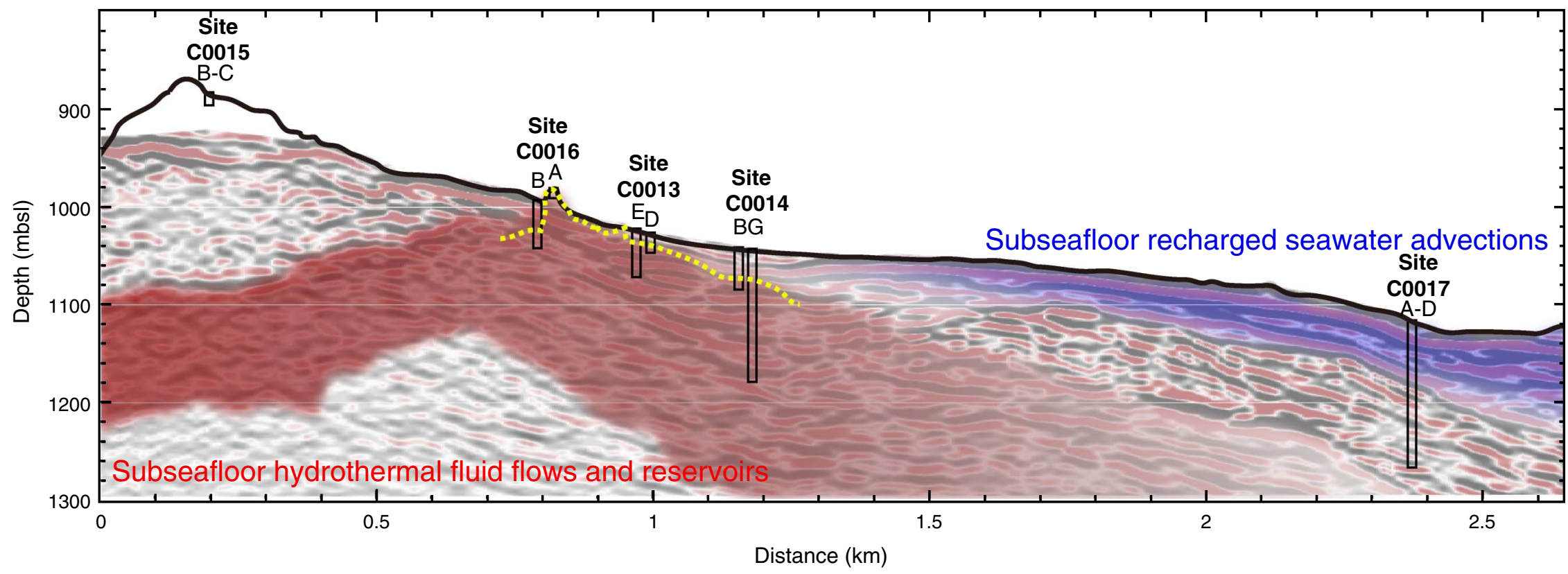


Table T1. Site surveys in the Iheya North hydrothermal field and the surrounding area.

\begin{tabular}{llll}
\hline \multicolumn{1}{c}{ Cruise name } & \multicolumn{1}{c}{ Vessel } & \multicolumn{1}{c}{ Period } & \multicolumn{1}{c}{ Site surveys } \\
\hline KR01-09 & Kairei & Jul-Aug 2001 & Heat flow, bathymetry, gravity, magnetism, subbottom profiling, coring \\
NT02-06 & Natsushima & Apr-May 2002 & Seafloor survey and sampling by submersible, heat flow \\
KY02-11 & Kaiyo & Nov-Dec 2002 & Multichannel seismic reflection survey \\
NT03-09 & Natsushima & Aug-Sep 2003 & Seafloor survey and sampling by ROV, heat flow \\
KY05-14 & Kaiyo & Jan 2005 & Heat flow, coring \\
YK06-09 & Yokosuka & Jul 2006 & Seafloor survey and sampling by submersible, single channel seismic reflection survey, heat flow \\
KY07-03 & Kaiyo & May 2007 & Multichannel seismic reflection survey \\
YK07-07 & Yokosuka & May 2007 & High-resolution of bathymetry, side-scan sonar imaging by autonomous underwater vehicle \\
NT07-11 & Natsushima & June 2007 & Seafloor survey and sampling by ROV, heat flow \\
NT07-13 & Natsushima & July 2007 & Seafloor survey and sampling by ROV, heat flow \\
KY08-01 Leg 2 & Kaiyo & Jan 2008 & Coring \\
KY08-01 Leg 3 & Kaiyo & Jan-Feb 2008 & Coring \\
KR10-02 & Kairei & Jan 2010 & Multichannel seismic reflection survey \\
\hline
\end{tabular}

ROV $=$ remotely operated vehicle.

Table T2. Coring summary, Expedition 331.

\begin{tabular}{|c|c|c|c|c|c|c|c|c|c|c|}
\hline Hole & Latitude & Longitude & $\begin{array}{l}\text { Water depth } \\
\quad(\text { mbsl) }\end{array}$ & $\begin{array}{l}\text { Cores } \\
(N)\end{array}$ & $\begin{array}{c}\text { Cored } \\
(\mathrm{m})\end{array}$ & $\begin{array}{l}\text { Recovered } \\
\quad(\mathrm{m})\end{array}$ & $\begin{array}{l}\text { Recovery } \\
\text { (\%) }\end{array}$ & $\begin{array}{l}\text { Drilled } \\
(\mathrm{m})\end{array}$ & $\begin{array}{l}\text { Penetration } \\
\quad(\mathrm{m})\end{array}$ & $\begin{array}{l}\text { Time on site } \\
\quad \text { (days) }\end{array}$ \\
\hline C0013A & $27^{\circ} 47.4150^{\prime} \mathrm{N}$ & $126^{\circ} 53.8605^{\prime} \mathrm{E}$ & 1035 & 1 & 7.0 & 0.00 & 0.0 & 0.0 & 7.0 & $<1$ \\
\hline C0013B & $27^{\circ} 47.4140^{\prime} \mathrm{N}$ & $126^{\circ} 53.8602^{\prime} \mathrm{E}$ & 1035 & 1 & 9.5 & 1.44 & 15.2 & 0.0 & 9.5 & $<1$ \\
\hline C0013C & $27^{\circ} 47.4119^{\prime} \mathrm{N}$ & $126^{\circ} 53.8606^{\prime} \mathrm{E}$ & 1035 & 1 & 9.5 & 9.70 & 102.1 & 3.0 & 12.5 & $<1$ \\
\hline C0013D & $27^{\circ} 47.4130^{\prime} \mathrm{N}$ & $126^{\circ} 53.8609^{\prime} \mathrm{E}$ & 1036.5 & 4 & 32.5 & 17.91 & 50.0 & 3.0 & 35.5 & $<1$ \\
\hline C0013E & $27^{\circ} 47.4157^{\prime} \mathrm{N}$ & $126^{\circ} 53.8546^{\prime} \mathrm{E}$ & 1034 & 8 & 45.0 & 11.59 & 35.4 & 9.8 & 54.5 & 3 \\
\hline C0013F & $27^{\circ} 47.4122^{\prime} \mathrm{N}$ & $126^{\circ} 53.8601^{\prime} \mathrm{E}$ & 1035.1 & 1 & 7.5 & 9.50 & 126.7 & 0.0 & 7.5 & $<1$ \\
\hline C0013G & $27^{\circ} 47.4100^{\prime} \mathrm{N}$ & $126^{\circ} 53.8554^{\prime} \mathrm{E}$ & 1035.1 & 1 & 1.8 & 1.80 & 100.0 & 7.5 & 9.3 & $<1$ \\
\hline \multirow[t]{2}{*}{$\mathrm{C} 0013 \mathrm{H}$} & $27^{\circ} 47.4098^{\prime} \mathrm{N}$ & $126^{\circ} 53.8565^{\prime} \mathrm{E}$ & 1035.1 & 1 & 0.6 & 0.60 & 100.0 & 9.3 & 9.9 & $<1$ \\
\hline & & \multicolumn{2}{|c|}{ Site C0013 totals: } & 18 & 113.4 & 52.54 & 46.3 & 32.6 & 145.7 & 7 \\
\hline C0014A & $27^{\circ} 47.4140^{\prime} \mathrm{N}$ & $126^{\circ} 54.0487^{\prime} \mathrm{E}$ & 1059.5 & 1 & 6.5 & 5.32 & 81.8 & 0.0 & 6.5 & $<1$ \\
\hline C0014B & $27^{\circ} 47.4131^{\prime} \mathrm{N}$ & $126^{\circ} 54.0448^{\prime} \mathrm{E}$ & 1059 & 5 & 44.5 & 45.01 & 101.5 & 0.0 & 44.5 & 1 \\
\hline C0014C & $27^{\circ} 47.4194^{\prime} \mathrm{N}$ & $126^{\circ} 54.0391^{\prime} \mathrm{E}$ & 1060 & 1 & 6.5 & 4.90 & 75.4 & 0.0 & 6.5 & $<1$ \\
\hline C0014D & $27^{\circ} 47.4158^{\prime} \mathrm{N}$ & $126^{\circ} 54.0406^{\prime} \mathrm{E}$ & 1060 & 2 & 16.0 & 12.50 & 79.1 & 0.0 & 16.0 & $<1$ \\
\hline C0014E & $27^{\circ} 47.4158^{\prime} \mathrm{N}$ & $126^{\circ} 54.0406^{\prime} \mathrm{E}$ & 1060 & 2 & 19.0 & 15.30 & 80.5 & 16.0 & 35.0 & $<1$ \\
\hline C0014F & $27^{\circ} 47.4185^{\prime} \mathrm{N}$ & $126^{\circ} 54.0443^{\prime} \mathrm{E}$ & 1060.8 & 1 & 4.2 & 4.20 & 100.0 & 0.0 & 4.2 & $<1$ \\
\hline \multirow[t]{2}{*}{ C0014G } & $27^{\circ} 47.4165^{\prime} \mathrm{N}$ & $126^{\circ} 54.0463^{\prime} \mathrm{E}$ & 1059.8 & 28 & 136.7 & 74.40 & 56.1 & 0.0 & 136.7 & 4 \\
\hline & & \multicolumn{2}{|c|}{ Site C0014 totals: } & 40 & 233.4 & 161.63 & 69.3 & 16.0 & 249.4 & 9 \\
\hline C0015A & $27^{\circ} 47.6678^{\prime} \mathrm{N}$ & $126^{\circ} 53.4981^{\prime} \mathrm{E}$ & 885 & 0 & 6.3 & 0.00 & 0.0 & 6.3 & 6.3 & $<1$ \\
\hline C0015B & $27^{\circ} 47.6673^{\prime} \mathrm{N}$ & $126^{\circ} 53.4981^{\prime} \mathrm{E}$ & 886 & 1 & 6.5 & 6.20 & 95.4 & 0.0 & 6.5 & $<1$ \\
\hline \multirow[t]{2}{*}{ C0015C } & $27^{\circ} 47.6689^{\prime} \mathrm{N}$ & $126^{\circ} 53.4993^{\prime} \mathrm{E}$ & 885.5 & 1 & 9.5 & 3.00 & 100.0 & 6.5 & 9.5 & $<1$ \\
\hline & & \multicolumn{2}{|c|}{ Site C0015 totals: } & 2 & 22.2 & 9.10 & 41.0 & 6.5 & 22.2 & $<1$ \\
\hline C0016A & $27^{\circ} 47.4548^{\prime} \mathrm{N}$ & $126^{\circ} 53.8034^{\prime} \mathrm{E}$ & 982 & 1 & 18.0 & 0.00 & 0.0 & 0.0 & 18.0 & 1 \\
\hline \multirow[t]{2}{*}{ C0016B } & $27^{\circ} 47.4538^{\prime} \mathrm{N}$ & $126^{\circ} 53.7860^{\prime} \mathrm{E}$ & 995 & 3 & 44.9 & 2.095 & 4.7 & 0.0 & 44.9 & 3 \\
\hline & & \multicolumn{2}{|c|}{ Site C0016 totals: } & 4 & 62.9 & 1.74 & 3.3 & 0.0 & 62.9 & 4 \\
\hline C0017A & $27^{\circ} 47.5030^{\prime} \mathrm{N}$ & $126^{\circ} 54.7176^{\prime} \mathrm{E}$ & 1129 & 1 & 8.8 & 8.80 & 100.0 & 0.0 & 8.8 & $<1$ \\
\hline C0017B & $27^{\circ} 47.5027^{\prime} \mathrm{N}$ & $126^{\circ} 54.7176^{\prime} \mathrm{E}$ & 1129 & 1 & 9.5 & 9.50 & 100.0 & 8.8 & 18.3 & $<1$ \\
\hline C0017C & $27^{\circ} 47.5039^{\prime} \mathrm{N}$ & $126^{\circ} 54.7202^{\prime} \mathrm{E}$ & 1129.6 & 2 & 19.0 & 18.00 & 94.8 & 31.0 & 50.0 & $<1$ \\
\hline \multirow[t]{3}{*}{ C0017D } & $27^{\circ} 47.5049^{\prime} \mathrm{N}$ & $126^{\circ} 54.7217^{\prime} \mathrm{E}$ & 1129.5 & 12 & 90.7 & 50.59 & 49.2 & 60.0 & 150.7 & 3 \\
\hline & & \multirow{2}{*}{\multicolumn{2}{|c|}{$\begin{array}{r}\text { Site } C 0017 \text { totals: } \\
\text { Expedition } 331 \text { totals: }\end{array}$}} & 16 & 128.0 & 86.89 & 67.9 & 99.8 & 227.8 & 3 \\
\hline & & & & 78 & 559.9 & 311.90 & 55.7 & 154.9 & 708.0 & 23 \\
\hline
\end{tabular}

